\title{
Transformation of terrestrial organic matter along thermokarst-affected permafrost coasts in the Arctic
}

\author{
George Tanski a,b,*, Hugues Lantuit ${ }^{\text {a,b }}$, Saskia Ruttor ${ }^{\text {a,b }}$, Christian Knoblauch ${ }^{\text {c }}$, Boris Radosavljevic ${ }^{\text {a,b }}$, \\ Jens Strauss ${ }^{\mathrm{a}}$, Juliane Wolter ${ }^{\mathrm{a}, \mathrm{b}}$, Anna M. Irrgang a,b ${ }^{\mathrm{a}}$, Justine Ramage ${ }^{\mathrm{a}, \mathrm{b}}$, Michael Fritz ${ }^{\mathrm{a}}$ \\ a Alfred Wegener Institute Helmholtz Centre for Polar and Marine Research, Periglacial Research Unit, Potsdam, Germany \\ b Potsdam University, Institute of Earth and Environmental Sciences, Potsdam, Germany

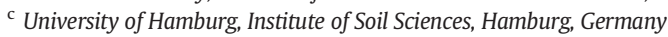

\section{H I G H L I G H T S}

- Terrestrial organic matter $(\mathrm{OM})$ is transformed by RTS before entering the ocean.

- RTSs induce drastic organic carbon and nitrogen losses of 77 and 53\%, respectively.

- Loss is caused by dilution with melting massive ice and mineralization of OM.

- Heavier portions of OM are directly buried in nearshore marine sediments.

- The Canadian Arctic is a key region for OM transformation, as RTS are ubiquitous.

\section{A R T I C L E I N F O}

\section{Article history:}

Received 23 November 2016

Received in revised form 22 December 2016

Accepted 22 December 2016

Available online 11 January 2017

Keywords:

Canadian Arctic

Coastal erosion

Retrogressive thaw slump

Biogeochemistry

Carbon degradation

\section{G R A P H I C A L A B S T R A C T}

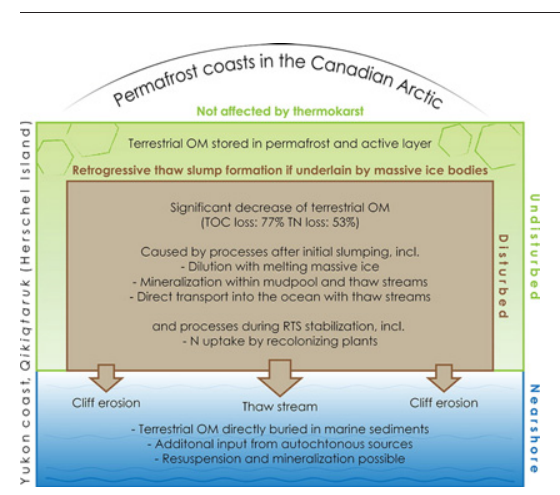

\begin{abstract}
A B S T R A C T
The changing climate in the Arctic has a profound impact on permafrost coasts, which are subject to intensified thermokarst formation and erosion. Consequently, terrestrial organic matter (OM) is mobilized and transported into the nearshore zone. Yet, little is known about the fate of mobilized OM before and after entering the ocean. In this study we investigated a retrogressive thaw slump (RTS) on Qikiqtaruk - Herschel Island (Yukon coast, Canada). The RTS was classified into an undisturbed, a disturbed (thermokarst-affected) and a nearshore zone and sampled systematically along transects. Samples were analyzed for total and dissolved organic carbon and nitrogen (TOC, DOC, TN, DN), stable carbon isotopes $\left(\delta^{13} \mathrm{C}-\mathrm{TOC}, \delta^{13} \mathrm{C}-\mathrm{DOC}\right)$, and dissolved inorganic nitrogen (DIN), which were compared between the zones. $\mathrm{C} / \mathrm{N}$-ratios, $\delta^{13} \mathrm{C}$ signatures, and ammonium $\left(\mathrm{NH}_{4}-\mathrm{N}\right)$ concentrations were used as indicators for OM degradation along with biomarkers ( $n$-alkanes, $n$-fatty acids, $n$-alcohols). Our results show that OM significantly decreases after disturbance with a TOC and DOC loss of 77 and $55 \%$ and a TN and DN loss of 53 and 48\%, respectively. C/N-ratios decrease significantly, whereas $\mathrm{NH}_{4}-\mathrm{N}$ concentrations slightly increase in freshly thawed material. In the nearshore zone, OM contents are comparable to the disturbed zone. We suggest that the strong decrease in OM is caused by initial dilution with melted massive ice and immediate offshore transport via the thaw stream. In the mudpool and thaw stream, OM is subject to degradation, whereas in the slump floor the nitrogen decrease is caused by recolonizing vegetation. Within the nearshore zone of the ocean, heavier portions of OM are directly buried in marine sediments close to shore. We conclude
\end{abstract}

\footnotetext{
* Corresponding author at: Alfred Wegener Institute Helmholtz Centre for Polar and Marine Research, Periglacial Research Unit, Telegrafenberg A43, 14473 Potsdam, Germany.

E-mail addresses: George.Tanski@awi.de (G. Tanski), Hugues.Lantuit@awi.de (H. Lantuit), saskia.ruttor@gmail.com (S. Ruttor), Christian.Knoblauch@uni-hamburg.de (C. Knoblauch), Boris.Radosavljevic@awi.de (B. Radosavljevic), Jens.Strauss@awi.de (J. Strauss), Juliane.Wolter@awi.de (J. Wolter), Anna.Irrgang@awi.de (A.M. Irrgang), Justine.Ramage@awi.de (J. Ramage), Michael.Fritz@awi.de (M. Fritz).
} 
that RTS have profound impacts on coastal environments in the Arctic. They mobilize nutrients from permafrost, substantially decrease OM contents and provide fresh water and nutrients at a point source.

(c) 2017 Elsevier B.V. All rights reserved.

\section{Introduction}

The Arctic is most affected by changing climate more than any other region on Earth. Models project a greater temperature increase than the global mean by the end of the 21st century, resulting in drastic impacts on Arctic environments (Collins et al., 2013; Forbes et al., 2011). Permafrost-affected soils in northern latitudes contain about 1300 Pg of organic carbon (OC), of which about $800 \mathrm{Pg}$ are permanently frozen (Hugelius et al., 2014), and 66 Pg nitrogen (N) in the uppermost $3 \mathrm{~m}$ (Harden et al., 2012). With warmer climate conditions, permafrost thaws and organic matter $(\mathrm{OM})$ that has been preserved for millennia is subject to degradation. That leads to increased greenhouse gas emissions and, ultimately, climate warming - a process known as the permafrost carbon feedback. However, due to the complexity of environmental processes, the intensity of this feedback remains unclear (Schaefer et al., 2014; Schuur et al., 2015). Besides being released as greenhouse gases, OM can be redeposited on land or transported to aquatic systems where it can be further mineralized in the water column or buried in sediments (Cory et al., 2013; Letscher et al., 2011; Vonk et al., 2014; Woods et al., 2011).

Thermokarst is a widespread phenomenon in the Arctic, characterized by ground disturbance and subsidence processes caused by the thawing of ice-rich permafrost (Czudek and Demek, 1970; Grosse et al., 2011; Schuur et al., 2008). It is of particular importance for the mobilization of $\mathrm{OM}$, as it triggers its release by disturbing the frozen ground (Abbott et al., 2015; Abbott and Jones, 2015; Bowden et al., 2008; Vonk et al., 2013). Thermokarst in upland, inland, sub-Arctic, and High Arctic permafrost regions, was intensively studied focusing on the lability of permafrost carbon, greenhouse gas emissions, release of nutrients (e.g., nitrogen, phosphorus, sulfur), and impacts on aquatic systems (Abbott et al., 2015; Cassidy et al., 2016; Frey et al., 2007; Kokelj et al., 2013; Turetsky et al., 2007). However, only a few studies are available on coastal thermokarst, which is ubiquitous along the ice-rich permafrost coasts in the Arctic, and on the fate of OM within the coastal environment (Lantuit et al., 2012a; Lantuit and Pollard, 2008; Pelletier and Medioli, 2014).

Retrogressive thaw slumps (RTS) are one of the most widespread thermokarst forms (Jorgenson and Osterkamp, 2005; Kokelj and Jorgenson, 2013; Krieger, 2012). Along with other degradation landforms, like active layer detachments and gullies, RTS can affect up to 1 to $2 \%$ of continuous permafrost areas (Krieger, 2012). RTS are widespread in the unlithified and ice-rich coastal parts of the western Canadian Arctic and are currently expanding in size and area (Lantuit and Pollard, 2008; Lantz and Kokelj, 2008; Pelletier and Medioli, 2014; Segal et al., 2016). RTS systems are typically active over decades and continuously mobilize terrestrial OM from permafrost, which has major impacts on the environment (Lantuit and Pollard, 2008; Lantz and Kokelj, 2008).

In this study, we investigate a coastal RTS located on Qikiqtaruk Herschel Island (Yukon Territory, Canada) and its effects on OM characteristics. The objectives of this study are (i) to quantify and compare $\mathrm{OM}$ contents in undisturbed and disturbed (thermokarst affected) zones of a RTS, (ii) to assess the transformation processes of OM after disturbance, and (iii) to track the fate of terrestrial OM in the nearshore zone. We hypothesize that OM stored in undisturbed coastal parts is substantially altered by thermokarst formation before entering the nearshore zone. We further hypothesize that OM mobilized from permafrost is subject to substantial degradation.

\section{Study area}

Our study area is Qikiqtaruk - Herschel Island $\left(69^{\circ} 34^{\prime} \mathrm{N} ; 138^{\circ} 55^{\prime} \mathrm{W}\right)$, which is situated approximately $2 \mathrm{~km}$ off the Yukon coast in the western Canadian Arctic (Fig. 1). The climate is polar continental, with mean annual air temperatures between -9.9 and $-11{ }^{\circ} \mathrm{C}$ (1970 to 2000) and precipitation between 161 and 254 mm year $^{-1}$ (Burn, 2012). The dominant wind direction is NW, with storms frequently observed in late August and September (Solomon, 2005). Herschel Island is an ice-thrust moraine ridge formed by glaciers during the Late Wisconsin Glaciation (23 to $18 \mathrm{ka} \mathrm{BP}$ ) and consists of unconsolidated and commonly finegrained former marine and glacigenic sediments (Blasco et al., 1990; Fritz et al., 2012). The island is underlain by continuous permafrost and characterized by polygonal tundra, valleys, and a rolling landscape that reaches a maximum elevation of $183 \mathrm{~m}$ above sea level (de Krom, 1990; Rampton, 1982). Permafrost on Qikiqtaruk is extremely ice-rich with mean ice volumes ranging between 30 and $60 \mathrm{vol} \%$, and up to values $>90 \mathrm{vol} \%$, when underlain by massive ground ice beds (Couture and Pollard, 2015; Fritz et al., 2015; Lantuit et al., 2012a). The active layer depth generally ranges between 40 and $60 \mathrm{~cm}$ in summer (Burn and Zhang, 2009; Kokelj et al., 2002). The vegetation on Qikiqtaruk is lowland tundra dominated by graminoids and dwarf shrubs, with a relatively species-rich forb flora and a well-developed moss layer (Kennedy et al., 2001; Myers-Smith et al., 2011; Smith et al., 1989). The open water season for the Beaufort Sea is 3 to 4 months (Dunton et al., 2006). Within that time frame, thermokarst and erosion processes affect the coastline and can trigger RTS. These systems are abundant on Qikiqtaruk and have doubled in area since 1950 (Lantuit and Pollard, 2008). The mean coastal erosion rate is $0.45 \mathrm{~m}$ year ${ }^{-1}$ (between 1970 and 2000), with strong erosion at sites with RTS systems and during storm events in autumn (Atkinson, 2005; Lantuit and Pollard, 2005; Obu et al., 2016; Solomon, 2005).

\section{Methods}

\subsection{Fieldwork and sampling}

We sampled active layer and permafrost sediments within the RTS "Slump-D" and marine sediments of the nearshore zone in the summers of 2013 and 2014 (Fig. 2). A summary of metadata for the samples is available in the Supplementary material (Table A.1). The RTS was divided into different zones and subzones based on direct field observations and Normalized Differenced Vegetation Index (NDVI) values (see Supplementary material, Fig. A.1). The NDVI was derived from a highresolution multispectral satellite image (GeoEye, $1.84 \mathrm{~m}$ multispectral resolution, acquired on 2011-09-08). We used the framework suggested by Lantuit and Pollard (2008) and classified the RTS into an undisturbed zone and a disturbed zone, which was affected by thermokarst (Table 1, Fig. 2). The undisturbed zone was further classified into the subzones active layer ( $\mathrm{AL}$ ) and permafrost (PF), and the disturbed zone into mudpool (MP), transition zone (TZ) and slump floor (SF). Moreover, we defined the thaw stream (TS) as the main channel draining the disturbed zone. The marine area adjacent to the RTS was classified as nearshore zone, with marine sediments from a short core (MS-SC) and surface sediments (MS-SU).

In total, 136 samples were taken on land and offshore (Fig. 3). The sampling design was based on GeoEye imagery. A fishnet raster was applied to determine sampling sites and avoid biased sampling within the 


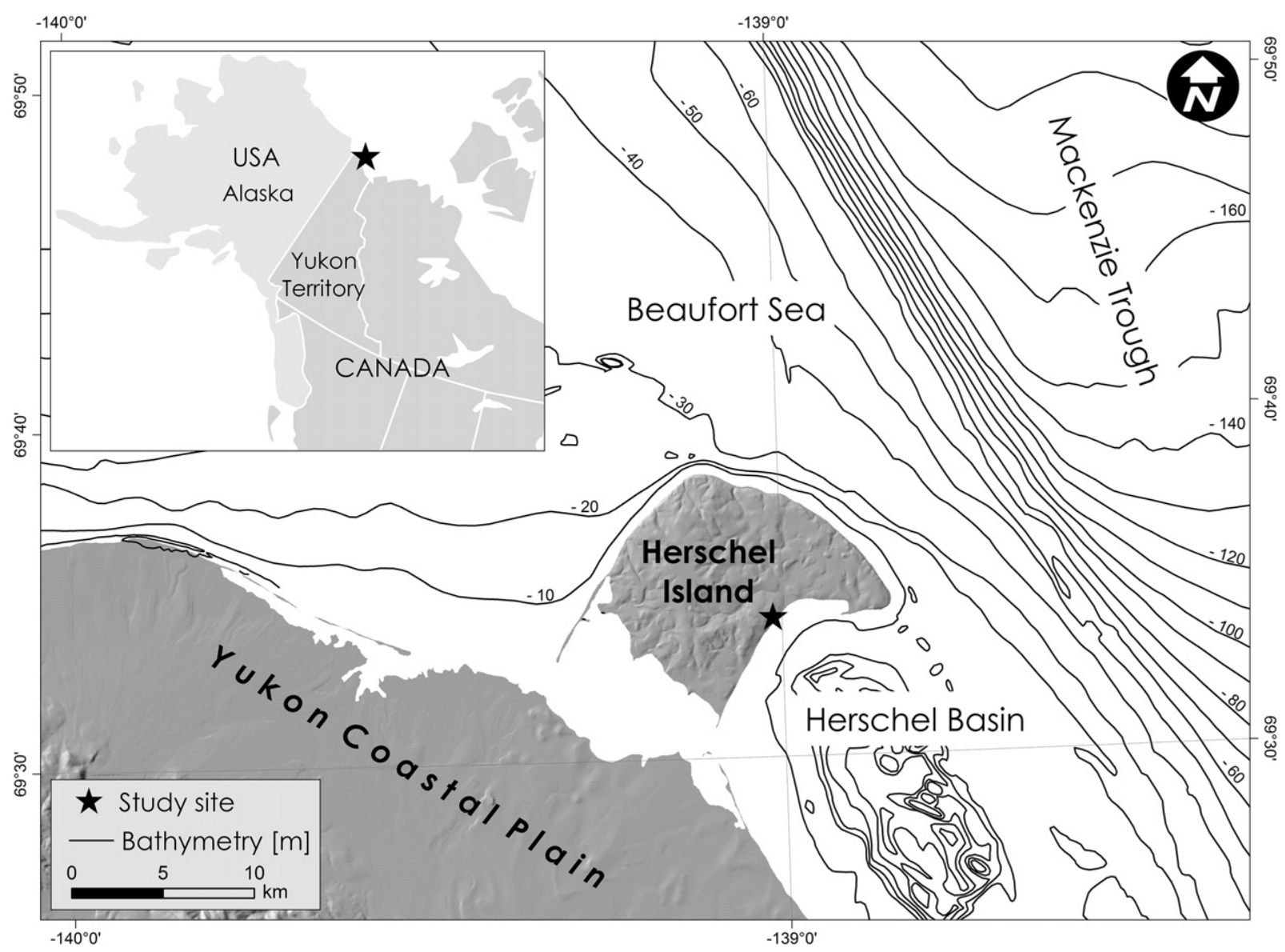

Fig. 1. Study area Qikiqtaruk - Herschel Island and study site, the retrogressive thaw slump "Slump-D."

RTS. The sampling targeted the upper $(10 \mathrm{~cm})$ and lower sediment columns $(30 \mathrm{~cm})$ of the active layer, transition zone, and slump floor, which were all non-frozen at the time of sampling. Permafrost samples were taken vertically throughout the entire exposed profile at the headwall (up to $\sim 350 \mathrm{~cm}$ below surface). Mudpool samples were taken from below the surface and thaw stream samples at the mouth of the RTS just before entering the ocean. In addition to terrestrial samples from the RTS, 23 marine samples were taken along a transect $2 \mathrm{~km}$

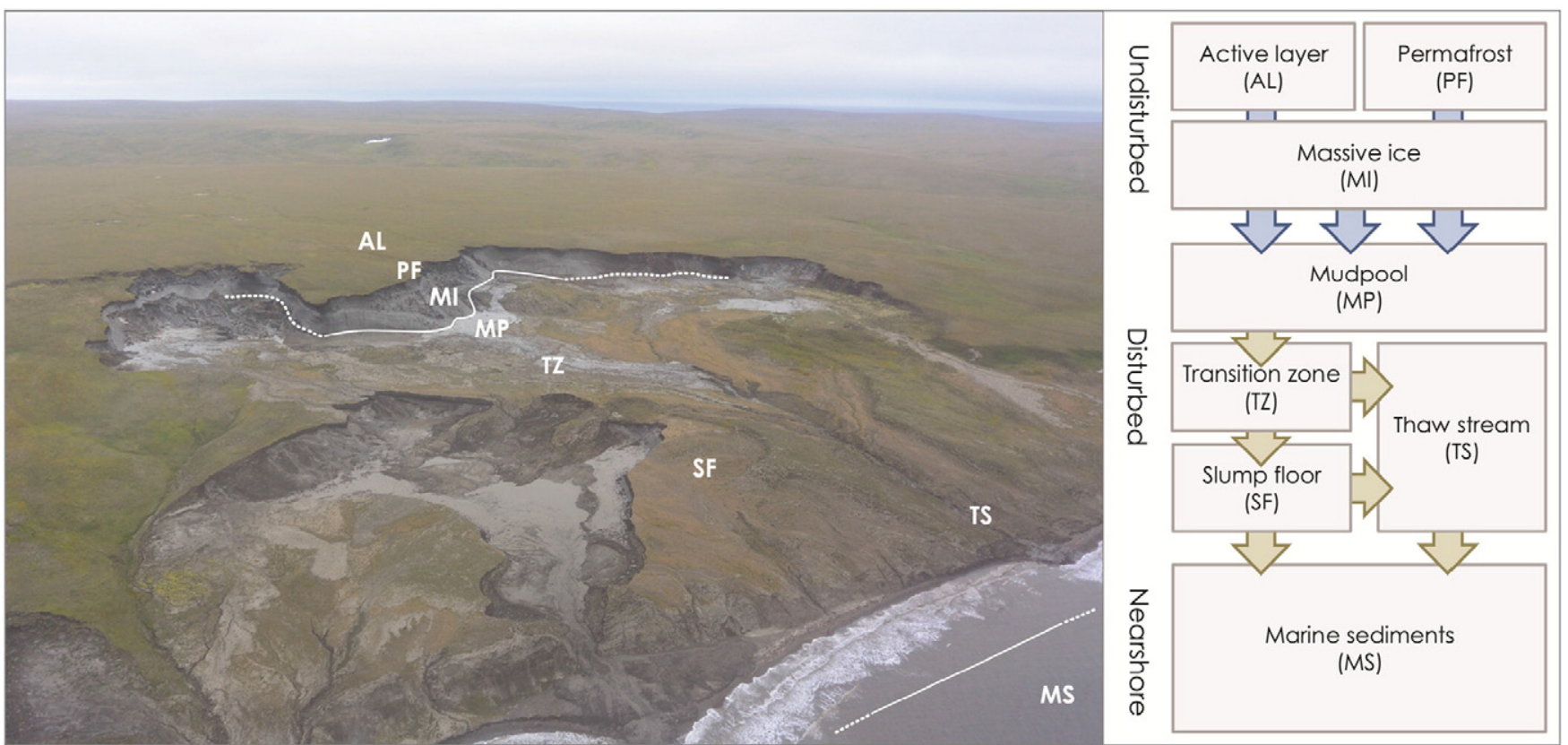

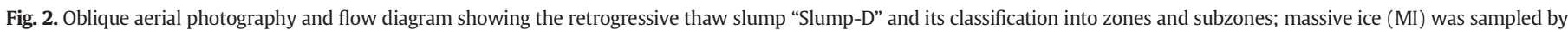
Tanski et al. (2016). 
Table 1

Classification and definition of the zones and subzones of the retrogressive thaw slump (RTS).

\begin{tabular}{|c|c|c|c|}
\hline Zone & Subzone & Definition & $\mathrm{n}$ \\
\hline Undisturbed & AL & Active layer above RTS headwall & 14 \\
\hline Undisturbed & $\mathrm{PF}$ & Permanently frozen sediments exposed in RTS headwall & 17 \\
\hline Disturbed & MP & Mixed pool of thawed permafrost, melted massive ice and collapsed tundra & 8 \\
\hline Disturbed & $\mathrm{TZ}$ & Transition zone between mudpool and slump floor & 12 \\
\hline Disturbed & SF & Accumulated sediments from headwall retreat of the RTS & 55 \\
\hline Disturbed & TS & Main channel draining the RTS through a system of gullies & 7 \\
\hline Nearshore & MS-SC & Marine sediments from short core (400 m distance to RTS) & 18 \\
\hline \multirow[t]{2}{*}{ Nearshore } & MS-SU & Marine surface sediments from sea floor (50-2000 m distance to RTS) & 5 \\
\hline & & & $\Sigma=136$ \\
\hline
\end{tabular}

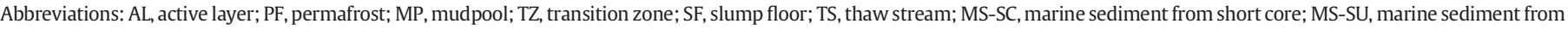
surface, $\mathrm{n}=$ sample size.

perpendicular to the RTS (Fig. 3). Marine sediments from the surface of the sea floor (MS-SU; on average $6 \mathrm{~cm}$ thick) were taken at 50,100, 400,800 , and $2000 \mathrm{~m}$ distance from the coast, with an additional short core (21 cm long) at $400 \mathrm{~m}$ distance (MS-SC).

A description of (cryo-)stratigraphy and vegetation was carried out at the sampling locations. Sediment samples from the active layer, mudpool, transition zone, and slump floor were taken with a stainless steel cylinder ( $6.3 \mathrm{~cm}$ diameter). Within the headwall, three permafrost profiles were sampled at different locations to a depth of 250 and $340 \mathrm{~cm}$ below surface using a rotary hammer (Hilti, Liechtenstein), axe and chisel. Thaw stream samples were taken using pre-cleaned HDPE bottles, after rinsing with sample material 3 to 5 times to avoid contamination, and were frozen until further processing. Marine sediments (MS-SC) were taken with a gravity corer (UWITEC, Austria) and a standard PVC tube ( $6.0 \mathrm{~cm}$ diameter). The $21 \mathrm{~cm}$-long core was split in the field into $1 \mathrm{~cm}$-thick slices. The additional marine surface sediments from the sea floor (MS-SU) were obtained with a Van Veen grab-sampler. Surface samples from sample MS-SU3 were taken from the upper $6 \mathrm{~cm}$ of the short core (MS-SC).

All samples were stored in plastic bags and the initial fresh weight was determined in the field. With the exception of marine sediments, all non-frozen sediments from active layer, mudpool, transition zone, and slump floor were treated on site with a soil moisture rhizon (0.2 $\mu \mathrm{m}$ pore size) to extract pore water and interstitial water.

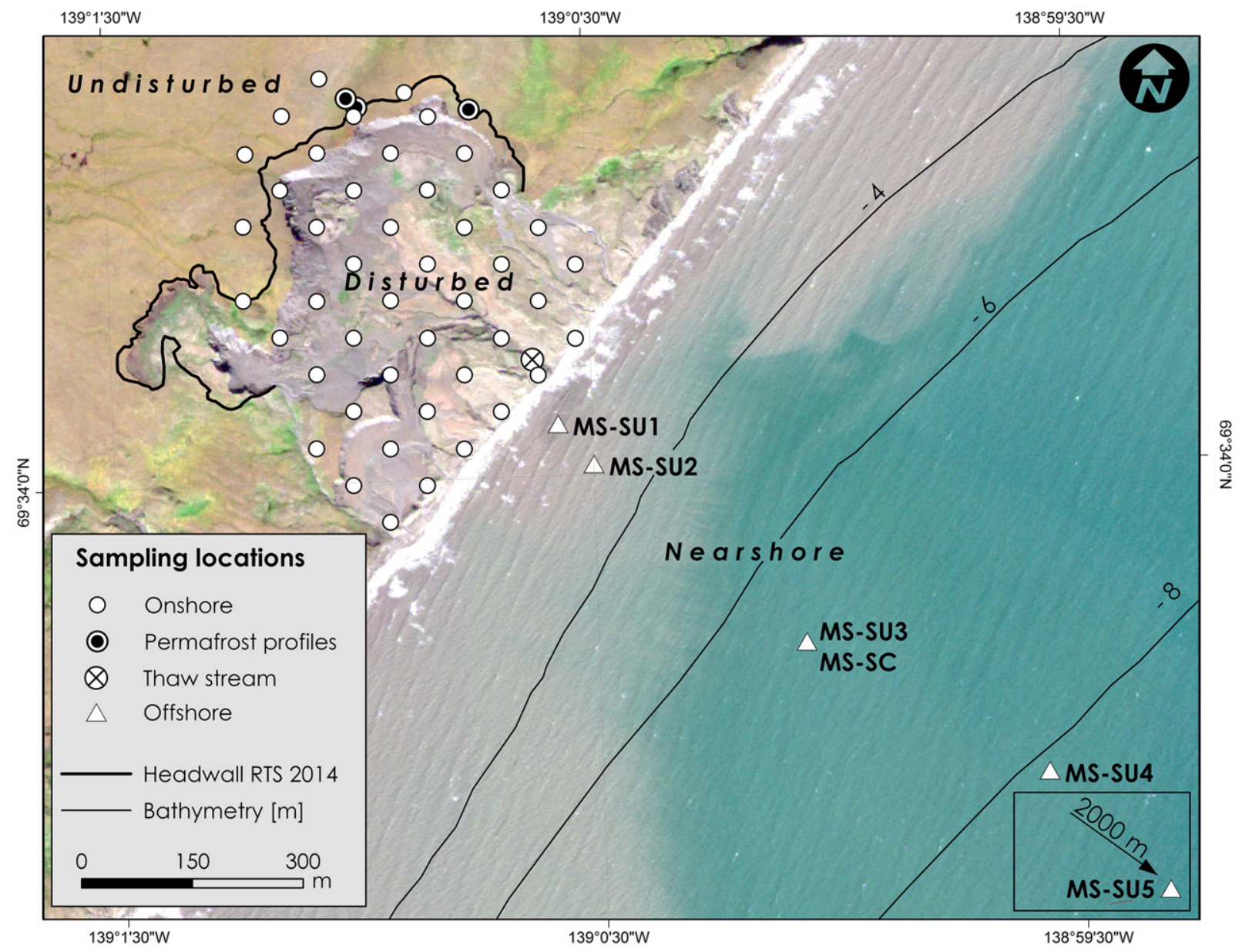

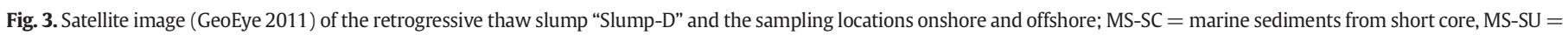
marine sediments from surface of the sea floor. 
Permafrost and thaw stream samples were kept frozen and dark during transportation, marine sediments cooled and dark, until further hydrochemical and geochemical analysis in Germany.

\subsection{Sedimentology, stratigraphy, and vegetation}

Samples were wet-weighed, freeze-dried, and dry-weighed to assess the water and ice content. The TOC pool in $\mathrm{kg} \mathrm{C} \mathrm{m}^{-3}$ soil was quantified using a common methodology given by Strauss et al. (2012). For ice-saturated permafrost samples ( $>20 \mathrm{wt} \%$ ), we assumed that the ice content was equivalent to the pore volume (Strauss et al., 2012). The ice volume $\left(\mathrm{V}_{\text {ice }}\right)$ was determined by multiplying the mass $\left(\mathrm{m}_{\text {ice }}\right)$ and volume of ice at $-10{ }^{\circ} \mathrm{C}\left(\rho_{\text {ice }}=0.91 \mathrm{~g} \mathrm{~cm}^{-3}\right.$; Lide et al., 2009). The TOC pool was estimated following Eq. (1), where $\rho_{\mathrm{b}}$ the bulk density $\left(\mathrm{g} \mathrm{cm}^{-3}\right)$. The bulk density was estimated according to Eq. (2), with $\rho_{s}$ being the density of solids $\left(\mathrm{g} \mathrm{cm}^{-3}\right), V_{p}$ the pore volume $\left(\mathrm{cm}^{-3}\right)$ and $V_{s}$ the volume of solids $\left(\mathrm{cm}^{-3}\right)$.

TOC pool $=\rho_{b} \cdot 1000 \cdot\left(\frac{\text { TOC wt } \%)}{100}\right)$

$\rho_{\mathrm{b}}=\left(\frac{\mathrm{Vp}}{\mathrm{Vp}+\mathrm{Vs}}-1\right) \cdot\left(\rho_{\mathrm{s}}\right)$

The cryostratigraphical description of permafrost followed the common terminology of French and Shur (2010). Vegetation descriptions were carried out on site and using photographs taken during fieldwork.

\subsection{Organic matter}

After freeze-drying and grinding the samples, total carbon (TC) and nitrogen (TN) contents were quantified using a Vario EL III elemental analyzer (Elementar, Germany). Total organic carbon (TOC) was analyzed with a Vario Max C analyzer (Elementar, Germany), including an automatic removal for inorganic carbon (carbonates). Stable carbon isotopes $\left(\delta^{13} \mathrm{C}-\mathrm{TOC}\right)$ were analyzed with a DELTAplusXL Finnigan mass spectrometer (Thermo Fisher Scientific, Germany) coupled to a Carlo-Erba NC2500 elemental analyzer. Isotope signatures are reported in per mille (\%) against Pee Dee Belemnite (VPDB).

The total carbon and nitrogen pools were further characterized by selected fractions. Dissolved organic carbon (DOC) and dissolved nitrogen (DN) were measured on a TOC-L analyzer with a TNM-L module (Shimadzu, Japan). Samples were acidified with $\mathrm{HCl}$ (30\% suprapur) prior to the measurement, and total inorganic carbon (TIC) was sparged out with synthetic air. Stable carbon isotopes of DOC $\left(\delta^{13} \mathrm{C}-\mathrm{DOC}\right)$ were determined with a DOC analyzer Aurora 1030 (OI Analytical, USA) connected to a Delta V Plus isotope ratio mass spectrometer (Thermo Fisher Scientific, Germany) following the method described by St-Jean (2003). Measurements were calibrated against the isotope standards USGS 40 $(-26.4 \%$ VPDB $)$ and IAEA C6 ( $-10.8 \%$ VPDB). Dissolved nitrite $\left(\mathrm{NO}_{2}-\mathrm{N}\right)$ and nitrate $\left(\mathrm{NO}_{3}-\mathrm{N}\right)$ were separated on a Hypersil 5 ODS column $\left(125 \times 4 \mathrm{~mm}^{-1}\right)$ and analyzed with a diode array detector on a 1200 series HPLC (Agilent Technologies, USA). The carrier solvent was a solution of $5 \%$ methanol and $4 \mathrm{mM}$ tetrabutylammoniumhydrogensulfate in water. Ammonium $\left(\mathrm{NH}_{4}-\mathrm{N}\right)$ was determined according to Krom and Berner (1980). The detection of $\mathrm{NH}_{4}-\mathrm{N}$ was done with a spectral photometer at $655 \mathrm{~nm}$ (Genesys10-s, Thermo Spectronic, USA).

Lipid biomarkers from plant waxes were measured with a GC-MS system (GC: Trace GC Ultra; MS: DSQ, both Thermo Fisher Scientific, Germany). A detailed description of the biomarker extraction, fraction separation, and measurement procedure is described in Strauss et al. (2015). The OM fractions used were $n$-alkanes, $n$-fatty acids, and $n$ alcohols. Prior to the measurements, $n$-fatty acids were methylated with diazomethane and the alcohols were silylated with $\mathrm{N}$-methyl- $\mathrm{N}$ - trimethylsilyltrifluoroacetamide (MSTFA). Quantification of $n$-alkanes, $n$-fatty acids, and $n$-alcohols was done using the software Xcalibur.

\subsection{Statistics}

We used a Mann-Whiney $U$ test $(\alpha=0.05)$ to identify whether the differences between the undisturbed and disturbed zone (excluding the thaw stream and marine sediments) were significant. The results are summarized in the Supplementary material (Table A.2). Box-whisker plots illustrate the results, and give the median (middle whiskers), the range of values (lower and upper whiskers), the 25\%- and 75\%-quartiles (lower and upper ends of the boxes), and outlier values (black diamonds below or above the whiskers).

\subsection{Transformation of organic matter}

\subsubsection{Dilution}

We used a simple theoretical experiment to show the possible impact of melting massive ice on OC contents in the disturbed zone. For this approach, we assumed a non-conservative mixing from active layer, permafrost and massive ice sources, disregarding processes such as in situ production, flocculation and degradation of OM (Stedmon and Markager, 2005). In addition to known DOC concentrations of active layer and permafrost (this study), DOC concentrations for massive ice $(n=16)$ were taken from Tanski et al. (2016). The volume of each feature in the headwall was calculated using its height. Heights for active layer $(\mathrm{n}=7)$ and permafrost $(\mathrm{n}=3)$ were taken with a measuring tape and an active layer probe. The approximate height of the massive ice bed was derived from a photograph (see Supplementary material, Fig. A.2). Ultimately, a weighted DOC concentration was calculated based on the volume of each feature and compared to the measured concentrations in the disturbed zone.

\subsubsection{Degradation}

We used several proxies for degradation in our study, including $\mathrm{C} / \mathrm{N}$-ratios, $\delta^{13} \mathrm{C}$ signatures, and inorganic nutrients in the form of $\mathrm{NH}_{4}-\mathrm{N}$ as indicators for turnover of OM and thus degradation. For three selected samples, we additionally used bulk biomarker measurements, which gave a rough estimate of OM quality and preservation.

The $\mathrm{C} / \mathrm{N}$-ratio and $\delta^{13} \mathrm{C}$ signatures indicate variations in bioproductivity, as well as OM preservation and degradation processes (Gundelwein et al., 2007; Kuhry and Vitt, 1996). The combination of both were used as decomposition indicators of OM following the approach of Stevenson (1994), which emphasizes changes in C/N-ratios after different OM components are selectively degraded.

Ammonification is the process of $\mathrm{NH}_{4}-\mathrm{N}$ release during the microbial mineralization of OM (Anand et al., 2011; Prosser, 1990). High microbial activity is responsible for high concentrations of $\mathrm{NH}_{4}-\mathrm{N}$ at low temperatures (Atkin, 1996; Kawahigashi et al., 2004). Therefore, we used $\mathrm{NH}_{4}{ }^{-}$ $\mathrm{N}$ concentrations as an indicator for $\mathrm{OM}$ mineralization.

Biomarkers are commonly used to characterize OM degradation (Andersson and Meyers, 2012). Based on the measurements of biomarkers ( $n$-alkanes, $n$-fatty acids, and $n$-alcohols), we calculated degradation proxies, following the approach given by Strauss et al. (2015; see Supplementary material A). Absolute lipid concentrations were used as a rough estimate of OM quality as follows: The higher the concentration, the better the conservation of the lipid, and the better the quality (i.e., less degraded) of the OM. Further, we used the carbon preference index (CPI), which gives the ratio of odd- to neighboring even-numbered alkanes, as an indicator for the alteration of OM (Bray and Evans, 1961). For the calculation of the CPI, we used the improved formula according to Marzi et al. (1993). In addition, we applied the CPI for fatty acids in which even-numbered fatty acids predominate over adjacent odd $n$-fatty acids. For $n$-alkanes, we used the $C_{23}-C_{33}$ interval, for $n$-fatty acids the $C_{20}-C_{34}$. A low CPI means mature or degraded OM (e.g., CPI of crude oil $\sim$ ). We also used hop-17(21)-ene as marker for 
estimating the maturity of the organic material. Hop-17(21)-ene is produced by bacteria. During degradation and diagenesis, the hop-17(21)ene will be transformed into saturated hopane (Luo et al., 2012). Thus, in comparison with the other samples, a high hop-17(21)-ene is interpreted as a lower maturity of the OM. The average chain length $(\mathrm{ACL})$ is a rough OC source parameter. A maturity proxy introduced by Poynter (1989), the higher plant alcohol (HPA) index, used the ratio of the major even wax alcohols over the sum of major odd wax alkanes plus even alcohols. It was applied as an indicator for the chemical degradation of the wax components. The general assumption for this index is that it reflects the preservation degree of the OM due to the higher lability of $n$-alcohols in relation to $n$-alkanes. As the absolute lipid and hop-17(21)-ene concentration, the HPA ratio cannot be considered as an absolute index of degradation, but as an indicator of the relative amounts of the more labile fatty acids that remain in a sample. Since $n$-alkanes are preserved preferentially compared to $n$-alcohols, a decrease in this index indicates increased decomposition (Poynter, 1989).

\subsection{Fate of organic matter in the nearshore zone}

Coastal sediments receive OM from autochtonous and allochtonous sources, which can be differentiated by their $\mathrm{C} / \mathrm{N}$-ratios and $\delta^{13} \mathrm{C}$ signatures (Lamb et al., 2006; Naidu et al., 2000). Stable carbon isotopes are indicative of the initial contribution of different plant species and plant components and therefore its terrestrial origin (Gundelwein et al., 2007). We used the combination of $\mathrm{C} / \mathrm{N}$-ratios and $\delta^{13} \mathrm{C}$ signatures in marine sediments as indicators of the terrestrial (allochtonous) and marine (autochtonous) origin of OM in marine sediments of the nearshore zone.

\section{Results}

\subsection{Sedimentology, stratigraphy, and vegetation}

\subsubsection{Undisturbed zone}

Soil profiles within the active layer are characterized by either undersaturated mineral sediments towards the outer parts or by water-saturated sediments towards the inner part of the RTS system. The median (and 25\%-75\%-quartile) water content is $30.8 \mathrm{wt} \%$ (20.0-50.5 wt\%). Both soil types are composed of silty sediment that is well-rooted and underlain by a layer of silt and clay towards the permafrost table. The active layer has an average thickness of $40 \mathrm{~cm}(\mathrm{n}=10)$ ranging from 26 to $56 \mathrm{~cm}$.

Permafrost is generally composed of silt and clay with an irregular reticulate cryostructure. Peaty inclusions and cryoturbation are common in the upper layer up to $1 \mathrm{~m}$ depth below surface. The profiles are icerich, with a median ice content of $57.1 \mathrm{wt} \%$ (38.7-64.2 wt\%). Permafrost sediments are intersected by ice wedges and underlain by massive ice bodies from approximately 3 to $5 \mathrm{~m}$ below surface.

The undisturbed zone is characterized by tussock tundra. The dominant vascular plant taxa are Eriophorum vaginatum, Salix spp. (S. arctica, S. pulchra, S. reticulata), Vaccinium vitis-idaea, and Arctagrostis latifolia. The outer part of the RTS, which is affected by slight surface creep, is dominated by Salix spp. (S. arctica, S. reticulata), Dryas integrifolia, Astragalus umbellatus, Lupinus arcticus, Eriophorum vaginatum, and Arctagrostis latifolia. At sites where surface creep is more intense, Salix spp. (S. arctica, S. pulchra, S. reticulata), Arctostaphylos alpina, Artemisia arctica, Petasites frigidus, and Arctagrostis latifolia dominate.

\subsubsection{Disturbed zone}

Sediments within the mudpool are water-saturated and consist of a mixture of greyish silt and clay. The median water content is $25.9 \mathrm{wt} \%$ (22.9-38.5 wt\%). Occasionally, smaller peat patches are buried below the surface of the mudpool. Larger peat blocks (i.e., hummocks) collapse from the active layer into the mudpool during headwall retreat and are either transported with the thaw stream directly into the nearshore zone or are buried permanently within the transition zone and the slump floor.

The transition zone lies between the solidifying part of the mudpool and the accumulations in the slump floor. This zone is drier than the mudpool and more compacted. Sediments are similar to those in the mudpool but with a lower median water content of $21.5 \mathrm{wt} \%$ (17.1$23.8 \mathrm{wt} \%$ ). Viscous mud is still prominent below the solidified surface. The surface of this zone supports a low vegetation cover. The abundant bare ground is covered by pioneer vegetation and characterized by $\mathrm{Se}$ necio congestus, Arctagrostis latifolia and an unidentified grass (cf. Poa pratensis ssp. alpigena), while mosses are sparse and lichens are absent.

The slump floor of the RTS is characterized by silty mineral sediments with higher OC contents (max.: $14.1 \mathrm{wt} \% \mathrm{TOC}$ ) when peat is buried. The median water content was 17.9 wt\% (16.9-20.7 wt\%). In some parts, older slump deposits are overflown by more recent mudflows draining the mudpool or are disturbed by small cracks, gullies, and channels. The vegetation changes drastically in the slump floor. In more recently disturbed areas, it resembles that of the transition zone, albeit with a denser vegetation cover and with Matricaria ambigua becoming abundant. Areas which were stable for a longer period host a more diverse vegetation, with nearly $100 \%$ cover. Shrubs (Salix arctica, S. reticulata), forbs (Aconitum delphinifolium, Astragalus umbellatus, Castilleja elegans, Dryas integrifolia, Equisetum arvense, Pedicularis spp.), and grasses (Arctagrostis latifolia) dominate. Mosses and occasional lichens (Cetraria cucullata) are also present.

\subsubsection{Thaw stream and nearshore zone}

The thaw stream is characterized by a steady water-saturated flow of fine-grained sediments. The median water content within the sediments of the thaw stream is $64.5 \mathrm{wt} \%$ (63.9-73.4 wt\%). Discharge quantity is variable and affected by meteorological conditions, including solar radiation, temperature, and precipitation.

The marine sediments from the short core and the additional marine surface sediments show a texture ranging from muddy, fine sand with peat inclusions to silty, bioturbated mud with increasing distance from the shore.

\subsection{Organic matter}

The following section summarizes the results from the analyses of organic carbon (TOC, DOC), nitrogen (TN, DN), and inorganic nitrogen (DIN), including ammonium $\left(\mathrm{NH}_{4}-\mathrm{N}\right)$, nitrite $\left(\mathrm{NO}_{2}-\mathrm{N}\right)$, and nitrate $\left(\mathrm{NO}_{3}-\mathrm{N}\right)$, as well as biomarkers in the different zones of the RTS. A summary of the results for the zones and subzones is available in the Supplementary material (Table A.2).

\subsubsection{Total and dissolved organic carbon}

TOC contents and pools are significantly different between the undisturbed and disturbed zone of the RTS (Fig. 4). Whereas the median TOC content in the undisturbed zone is $4.7 \mathrm{wt} \%$ (2.2-8.8 wt\%) and TOC pools $39.2 \mathrm{~kg} \mathrm{C} \mathrm{m}^{-3}\left(17.0-58.5 \mathrm{~kg} \mathrm{C} \mathrm{m}^{-3}\right)$, they significantly decrease in the disturbed zone to $1.1 \mathrm{wt} \%(0.9-1.5 \mathrm{wt} \% ; p=0.0002)$ and $17.5 \mathrm{~kg} \mathrm{C} \mathrm{m}^{-3}\left(12.4-29.0 \mathrm{~kg} \mathrm{C} \mathrm{m}^{-3}, p=0.007\right)$. Within the undisturbed zone, samples from the active layer and permafrost have similar TOC contents but the active layer has a much larger TOC pool than the permafrost (see Supplementary material, Table A.2). The TOC contents in the disturbed zone are similarly low in the mudpool, transition zone, and slump floor. The TOC pool increases with a decrease in water content towards the slump floor. In contrast to the disturbed zone, the TOC content of marine sediments in the nearshore zone remains stable at 1.4 wt\% (1.1$1.9 \mathrm{wt} \%$ ) within the short core (MS-SC) and $1.1 \mathrm{wt} \%$ (1.1-2.1 wt\%) within marine surface samples (MS-SU). Elevated TOC contents are detected in MS-SU2 and MS-SU3 at 1.5 and $2.7 \mathrm{wt} \%$, respectively, and in the lower part $(19 \mathrm{~cm})$ of the short core MS-SC at $2.4 \mathrm{wt} \%$. 


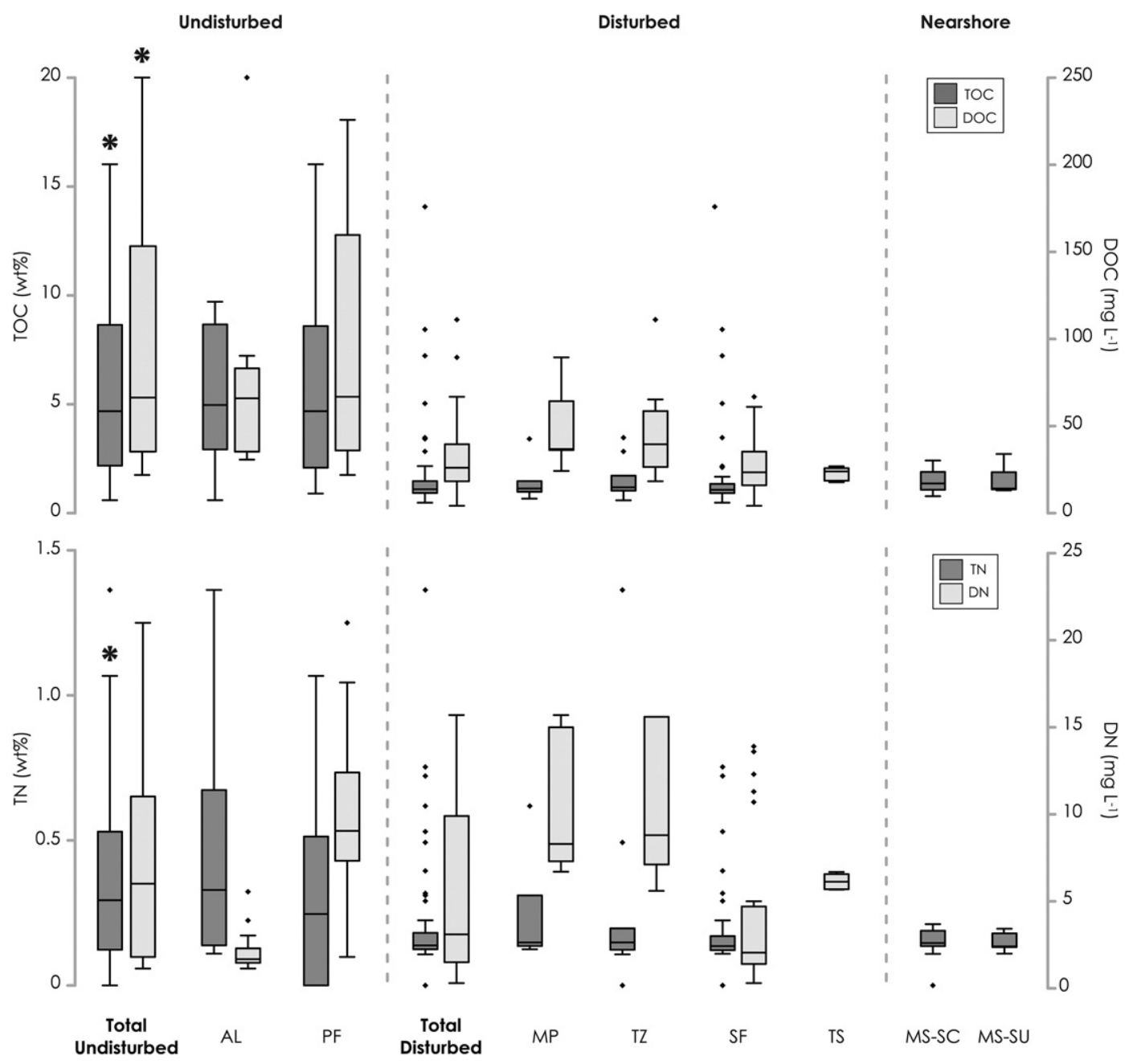

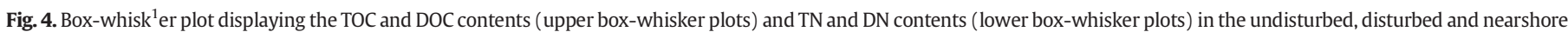

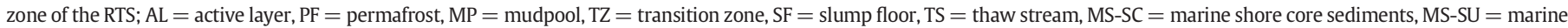

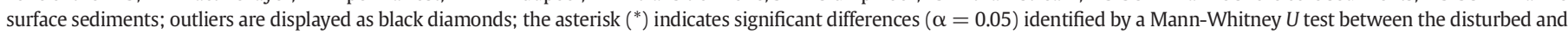

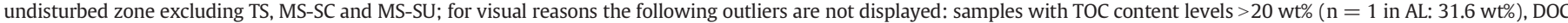
concentrations $>250 \mathrm{mg} \mathrm{L}^{-1}\left(\mathrm{n}=1\right.$ in AL: $\left.417.6 \mathrm{mg} \mathrm{L}^{-1}\right)$, and DN concentration $>25 \mathrm{mg} \mathrm{L}^{-1}(\mathrm{n}=2$ in MP, $\mathrm{max}: 89.3 \mathrm{mg} \mathrm{L}-1$; $n=5$ in SF, max: $174.9 \mathrm{mg} \mathrm{L}-1$.

DOC shows a similar pattern as TOC, with median concentrations decreasing significantly $(p=<0.0000)$ from $66.3 \mathrm{mg} \mathrm{L}^{-1}(35.0-$ $\left.154.9 \mathrm{mg} \mathrm{L}^{-1}\right)$ in the undisturbed zone to $26.5 \mathrm{mg} \mathrm{L}^{-1}$ (18.3$39.5 \mathrm{mg} \mathrm{L}^{-1}$ ) in the disturbed zone (Fig. 4). Within the disturbed zone, DOC concentrations decrease from $36.9 \mathrm{mg} \mathrm{L}^{-1}\left(32.1-57.8 \mathrm{mg} \mathrm{L}^{-1}\right)$ in the mudpool to $23.5 \mathrm{mg} \mathrm{L}^{-1}$ (15.9-35.0 $\mathrm{mg} \mathrm{L}^{-1}$ ) in the slump floor. Similar low DOC concentrations are detected in the thaw stream, at $24.0 \mathrm{mg} \mathrm{L}^{-1}\left(18.6-25.8 \mathrm{mg} \mathrm{L}^{-1}\right)$.

The calculated DOC concentrations from the dilution model give a value of $13.9 \mathrm{mg} \mathrm{L}^{-1}$ after theoretical dilution with melted massive ice

Table 2

Calculated DOC concentrations in the undisturbed zone after dilution with melted massive ice.

\begin{tabular}{llll}
\hline Feature & $\begin{array}{l}\text { Height } \\
(\mathrm{m})\end{array}$ & $\begin{array}{l}\text { Volume } \\
(\%)\end{array}$ & $\begin{array}{l}\mathrm{DOC}^{\mathrm{a}} \\
\left(\mathrm{mg} \mathrm{L}^{-1}\right)\end{array}$ \\
\hline Active layer (AL) & 0.4 & 3 & 65.9 \\
Permafrost (PF) & 2.5 & 14 & 66.8 \\
Massive ice (MI) & 14.0 & 83 & 2.9 \\
Weighted average after dilution (AL, PF, MI) & - & - & 13.9 \\
\hline
\end{tabular}

${ }^{a}$ Data are given as weighted averages according to the volume of each feature; DOC values for massive ice are from Tanski et al. (2016).
(Table 2). This number is much lower than the median concentration in the disturbed zone (see above).

\subsubsection{Total and dissolved nitrogen}

TN contents are significantly different after disturbance. Statistically higher TN contents $(p=0.009)$ are detected in the undisturbed zone at $0.3 \mathrm{wt} \%(0.1-0.5 \mathrm{wt} \%)$ than in the disturbed zone at $0.1 \mathrm{wt} \%(0.1-$ $0.2 \mathrm{wt} \%)$. For the active layer and permafrost, TN contents are similar but slightly higher in the active layer (Fig. 4). Within the disturbed zone, TN contents are very similar at $0.1 \mathrm{wt} \% \mathrm{TN}$ in all subzones. This continues in the nearshore zone with $0.1 \mathrm{wt} \%$ (0.1-0.2 wt\%) for marine sediments (MS-SC and MS-SU). Elevated TN contents are detected in the lower part $(19 \mathrm{~cm})$ of the short core (MS-SC) at $0.2 \mathrm{wt} \%$.

DN displays a different pattern (Fig. 4 ). DN does not significantly differ between the undisturbed zone with $6.0 \mathrm{mg} \mathrm{L}^{-1}\left(1.8-11.1 \mathrm{mg} \mathrm{L}^{-1}\right)$ and the disturbed zone at $1.7 \mathrm{mg} \mathrm{L}^{-1}\left(1.5-9.9 \mathrm{mg} \mathrm{L}^{-1}\right)$, but varies considerably between and within the zones. Whereas values in the active layer are low at $1.7 \mathrm{mg} \mathrm{L}^{-1}\left(1.4-2.7 \mathrm{mg} \mathrm{L}^{-1}\right)$ and narrow in their range of values, DN concentrations in permafrost are higher with $9.0 \mathrm{mg} \mathrm{L}^{-1}\left(7.2-12.7 \mathrm{mg} \mathrm{L}^{-1}\right)$ and have a wider range. This contrast in values is similar in the disturbed zone, where DN concentrations are high in the mudpool at $8.3 \mathrm{mg} \mathrm{L}^{-1}\left(7.1-13.7 \mathrm{mg} \mathrm{L}^{-1}\right)$ and transition 
zone at $8.8 \mathrm{mg} \mathrm{L}^{-1}$ (7.1-15.6 $\left.\mathrm{mg} \mathrm{L}^{-1}\right)$ and much lower in the slump floor with $2.1 \mathrm{mg} \mathrm{L}^{-1}\left(1.3-4.4 \mathrm{mg} \mathrm{L}^{-1}\right)$ and thaw stream with $6.1 \mathrm{mg} \mathrm{L}^{-1}$ (5.7-6.6 $\mathrm{mg} \mathrm{L}^{-1}$ ). Despite the general low DN concentrations in the slump floor, several outliers reach peak values as high as $174.9 \mathrm{mg} \mathrm{L}^{-1}$.

\subsubsection{Dissolved inorganic nitrogen (DIN)}

DIN concentrations are not significantly different $(p=0.1)$ between the undisturbed zone with $3.0 \mathrm{mg} \mathrm{L}^{-1}\left(0.1-4.8 \mathrm{mg} \mathrm{L}^{-1}\right)$ and the disturbed zone with $1.6 \mathrm{mg} \mathrm{L}^{-1}\left(0.2-5.8 \mathrm{mg} \mathrm{L}^{-1}\right)$, but decrease substantially and vary strongly within both zones (Fig. 5). In the undisturbed zone, practically no DIN is stored in the active layer, whereas almost the entire DIN is locked in permafrost at $4.7 \mathrm{mg} \mathrm{L}^{-1}$ (3.7$\left.5.3 \mathrm{mg} \mathrm{L}^{-1}\right)$. Within the disturbed zone, DIN values increase considerably in the mudpool to $5.2 \mathrm{mg} \mathrm{L}^{-1}\left(3.7-6.4 \mathrm{mg} \mathrm{L}^{-1}\right.$ ) and the transition zone to $4.4 \mathrm{mg} \mathrm{L}^{-1}$ (3.3-11.8 $\left.\mathrm{mg} \mathrm{L}^{-1}\right)$, and decrease sharply to very low concentrations in the slump floor at $0.5 \mathrm{mg} \mathrm{L}^{-1}\left(0.2-2.0 \mathrm{mg} \mathrm{L}^{-1}\right)$. In the latter zones mentioned, the number of outliers increases with very high peak values up to $77.3 \mathrm{mg} \mathrm{L}^{-1}$ in the transition zone and

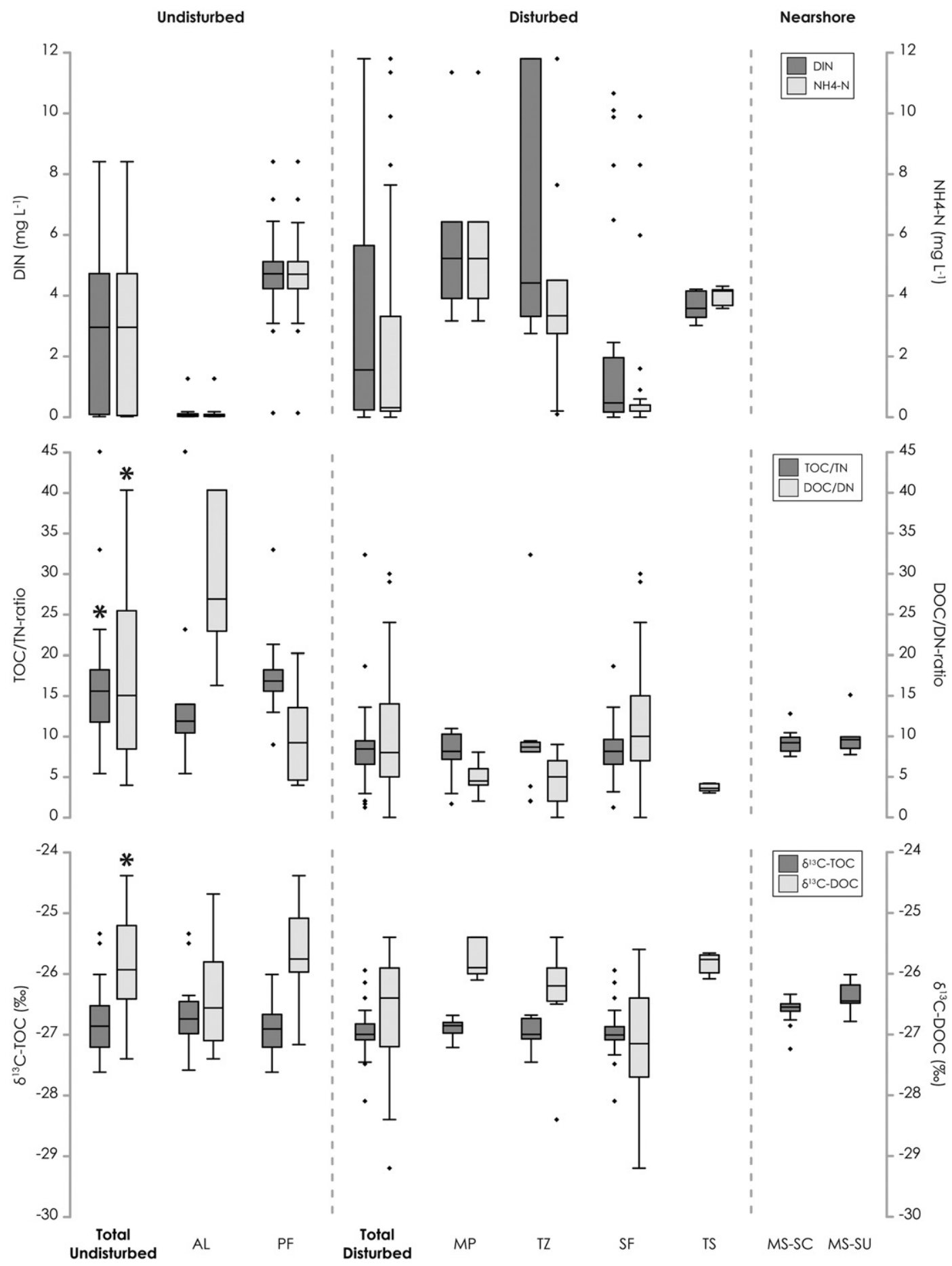

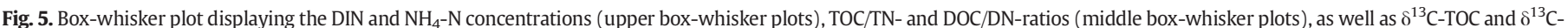

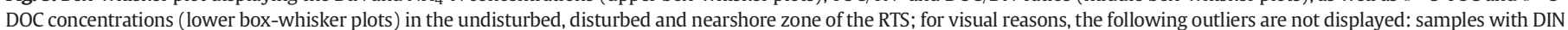

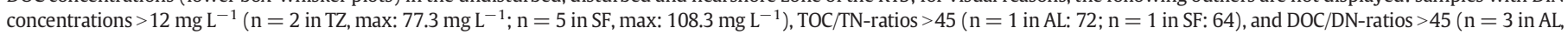
max: $107 ; \mathrm{n}=2$ in SF, $\max : 51$ ). 
$108.3 \mathrm{mg} \mathrm{L}^{-1}$ in the slump floor. The thaw stream has considerably high DIN concentrations of $4.2 \mathrm{mg} \mathrm{L}^{-1}\left(3.7-4.2 \mathrm{mg} \mathrm{L}^{-1}\right)$ comparable to those of the mudpool and transition zone.

Statistically, there is no significant difference between the $\mathrm{NH}_{4}-\mathrm{N}$ concentrations of the undisturbed zone at $3.0 \mathrm{mg} \mathrm{L}^{-1}\left(0.1-4.8 \mathrm{mg} \mathrm{L}^{-1}\right)$ and the disturbed zone at $0.3 \mathrm{mg} \mathrm{L}^{-1}\left(0.2-3.3 \mathrm{mg} \mathrm{L}^{-1}\right.$; Fig. 5), but other differences are substantial. Following the pattern of DIN, ammonium concentrations within the undisturbed zone are virtually zero in the active layer and higher in the permafrost at $4.7 \mathrm{mg} \mathrm{L}^{-1}\left(3.7-5.3 \mathrm{mg} \mathrm{L}^{-1}\right)$. Within the mudpool, $\mathrm{NH}_{4}-\mathrm{N}$ concentrations increase to $5.2 \mathrm{mg} \mathrm{L}^{-1}$ (3.7$6.4 \mathrm{mg} \mathrm{L}^{-1}$ ). As DIN, ammonium concentrations decrease drastically towards the slump floor with an increase in the quantity of outliers with maximum values of $11.8 \mathrm{mg} \mathrm{L}^{-1}$ in the transition zone and $9.9 \mathrm{mg} \mathrm{L}^{-1}$ in the slump floor (see Supplementary material, Table A.2). Whereas in the transition zone $\mathrm{NH}_{4}-\mathrm{N}$ concentrations are still considerably high at $3.3 \mathrm{mg} \mathrm{L}^{-1}\left(2.8-4.5 \mathrm{mg} \mathrm{L}^{-1}\right)$, they are very low in the slump floor at $0.2 \mathrm{mg} \mathrm{L}^{-1}\left(0.2-0.4 \mathrm{mg} \mathrm{L}^{-1}\right)$. The thaw stream shows considerably high values of $4.2 \mathrm{mg} \mathrm{L}^{-1}\left(3.7-4.2 \mathrm{mg} \mathrm{L}^{-1}\right)$ comparable to those in the mudpool.

Median nitrite and nitrate concentrations are zero in all zones and subzones. Noticeable concentrations are detected only in the transition zone and the slump floor as individual outliers (e.g., 0.7 and $3.1 \mathrm{mg} \mathrm{L}^{-1}$; see Supplementary material, Table A.1). For $\mathrm{NO}_{3}-\mathrm{N}$, the pattern is similar. Almost all samples have concentrations $<0.1 \mathrm{mg} \mathrm{L}^{-1}$. Only in individual samples of the transition zone and the slump floor concentrations of up to 76.6 and $107.9 \mathrm{mg} \mathrm{L}^{-1} \mathrm{NO}_{3}-\mathrm{N}$ are detected, respectively (see Supplementary material, Table A.1).

\section{3. $\mathrm{C} / \mathrm{N}$-ratios and $\delta^{13} \mathrm{C}$}

TOC/TN-ratios as well as DOC/DN-ratios are significantly different between the undisturbed and disturbed zone of the RTS ( $p=<0.0000$ and $p=0.0003$, respectively). The TOC/TN-ratios decrease from 16 (12-18) to 8 (6-10) and DOC/DN-ratios from 15 (8-26) to 8 (5-14; Fig. 5). Generally, TOC/TN-ratios remain low at $\sim 8$ within the disturbed zone, but are particularly lower for the dissolved fraction, with ratios of $\sim 5$ in the mudpool, transition zone, and thaw stream. Slightly higher DOC/DN-ratios with a larger range of values are detected in the slump floor of 10 (6-15). In the marine sediments (MS-SC and MS-SU), TOC/ TN-ratios are similar as in the disturbed zone but with a very small range of values. An elevated TOC/TN-ratio of 15 is observed for MS$\mathrm{SU} 2$ at a $100 \mathrm{~m}$ distance from the RTS. For stable carbon isotopes $\left(\delta^{13} \mathrm{C}-\mathrm{TOC}\right)$, no significant differences are found $(p=0.06)$ between $u n-$ disturbed and disturbed zone, with the majority of values ranging between approximately -26 and $-28 \%$ (Fig. 5). Isotopic signatures differ little yet significantly $(p=0.005)$ for the dissolved fraction $\left(\delta^{13} \mathrm{C}-\mathrm{DOC}\right)$, decreasing from $-25.9 \%$ o $(-26.4$ to $-25.2 \%$ o in the undisturbed to $-26.4 \%$ o ( -27.3 to $-25.9 \%$ ) in the disturbed zone.

\subsection{Biomarkers}

Biomarkers within the disturbed zone differ strongly between samples from the mudpool and the slump floor (Fig. 6). Sample H12-01 from the slump floor is most likely a peat intrusion buried in the slump deposits, indicated by a much higher TOC content. Absolute lipid concentrations of $n$-fatty acids decrease strongly from the mudpool $\left(\sim 3500 \mu \mathrm{g} \mathrm{g}^{-1} \mathrm{TOC}_{\mathrm{wt} \%}\right)$ to the slump floor $\left(\sim 2000 \mu \mathrm{g} \mathrm{g}^{-1} \mathrm{TOC}_{\mathrm{wt} \%}\right)$ and are especially low in the buried peat intrusion at $\sim 1000 \mu \mathrm{g} \mathrm{g}^{-1} \mathrm{TOC}_{\mathrm{wt} \%}$ (sample H12-01). Concentrations of $n$-alkanes are much lower at $100 \mu \mathrm{g} \mathrm{g}^{-1} \mathrm{TOC}_{\mathrm{wt}}$, but elevated in the peat intrusion at $\sim 800 \mu \mathrm{g} \mathrm{g}^{-1}$ $\mathrm{TOC}_{\mathrm{wt} \%}$. The CPI is similar for all samples, with much lower values for $n$-fatty acids $(\sim 8)$ than for $n$-alkanes $(\sim 30)$. Hop-17(21)-ene is low (close to zero) in both samples from the mudpool and the slump floor close to the cliff, but elevated in the peat intrusion to $>200 \mu \mathrm{g} \mathrm{g}^{-1}$ $\mathrm{TOC}_{\mathrm{wt} \%}$. The ACL is similar for all samples, with around $24 \pm 0.2$ (mean \pm standard deviation) for $n$-fatty acids and $28 \pm 0.1$ for $n$ -
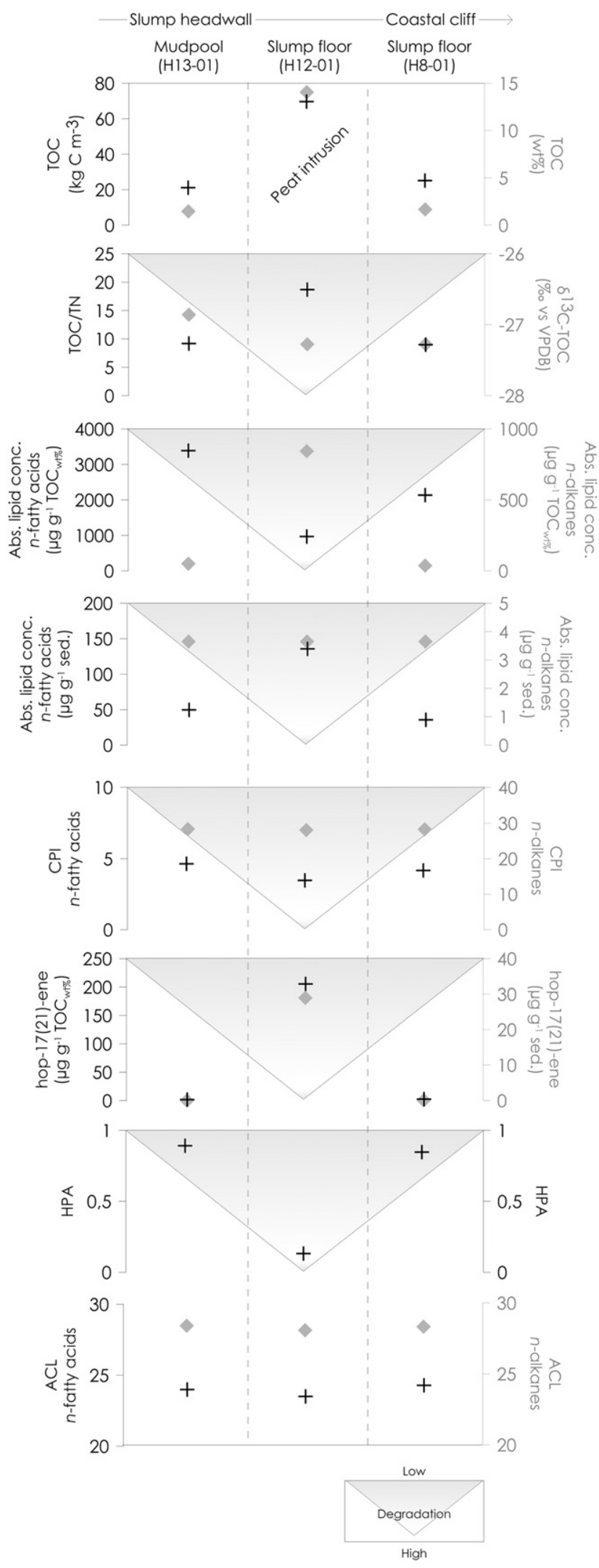

Fig. 6. Summary of biomarker data in three selected samples from the mudpool and slump floor; $\mathrm{CPI}=$ carbon preference index, $\mathrm{HPA}=$ higher plant alcohol, $\mathrm{ACL}=$ average chain length. Black crosses refer to the left y-axis, grey diamonds to the right $\mathrm{y}$-axis.

alkanes. The HPA shows no differences between the mudpool and the slump floor close to the coastal cliff, and is nearly 1 . In the buried peat sample, the HPA is much lower at $\sim 0.2$. 


\section{Discussion}

\subsection{Transformation of organic matter in the disturbed zone}

RTS formation at Qikiqtaruk is causing a substantial loss of organic carbon. TOC contents in the disturbed zone (excluding thaw stream and marine sediments) decrease by nearly $80 \%$, with a loss of $>60 \%$ for DOC. For TN and DN, the loss is only slightly smaller at $53 \%$ and $48 \%$, respectively. This is in good agreement with other studies conducted in the North American Arctic. Abbott and Jones (2015) show a TOC loss of $51 \%$ for the upper $35 \mathrm{~cm}$ by comparing tundra and slump deposits in upland permafrost regions in Alaska (USA). In the western Canadian Arctic, this is similar. Pizano et al. (2014) show that TOC pools in modern slump deposits are about three times smaller than in the undisturbed tundra, estimating a loss of 48 and 52\% carbon and nitrogen, respectively. A completely different picture is given by Strauss et al. (2015) or Weiss et al. (2015) for the Siberian Arctic, where thermokarst deposits have higher TOC contents than the contributing disturbed organic-rich Yedoma deposits, probably due to the concentration of redeposited OC. However, thermokarst deposits in these studies originate from drained, refrozen and stabilized lake basins and cannot be directly compared.

\subsubsection{Processes after initial slumping}

Within the mudpool, the initial slumping triggers a set of simultaneous processes, transforming and altering the geochemical characteristics of OM drastically. A major process is the dilution and mixing with melted massive ice beds that underlie the RTS or ice wedges that intersect the permafrost exposures in the headwall. Both consist of nearly pure ice ( $99 \%)$, contain very low amounts of OC, and take up $~ 28 \%$ of the total sediment volume at our study site (Couture and Pollard, 2015; Fritz et al., 2015; Tanski et al., 2016). With initial slumping, the massive ice melts and dilutes OC derived from the active layer and thawed permafrost, partially explaining the loss of $\mathrm{OC}$ in the disturbed zone. Although we only used a simplified theoretical approach, it shows that OC originating from the active layer and permafrost is probably highly diluted with water from melted massive ice, which could be one explanation for the abrupt OC decrease in the disturbed zone. This dilution effect probably has a similar impact on nitrogen, but no data for massive ice are available.

Contemporaneous to dilution within the mudpool, particulate organic carbon (POC) is likely subject to leaching and degradation processes and is transferred to the DOC pool, due to prolonged contact of water with the surrounding sediment (Fritz et al., 2011; Zimov et al., 2006). This is indicated by a stronger decrease of overall TOC rather than of DOC concentrations. Leaching of POC is supported by the studies of Artinger et al. (2000), who reported that DOC in the form of humic acids can originate from sediment $\mathrm{OC}$, as well as by Dou et al. (2008) who showed that different solutions have the potential to leach DOC from POC. Tanski et al. (2016) showed a very strong correlation between sediment contents and DOC concentrations within massive ice, most likely due to prolonged contact of meltwater during segregation. Also, Abbott et al. (2015) showed that DOC can be taken up by water flowing over thermokarst into the ocean. Melting snow patches that remain on the inclined surface of the massive ice bed, which can remain throughout the summer, could further facilitate the leaching process due to its initial purity and low ion content (Fritz et al., 2015). Guo et al. (2007) showed that during snowmelt fresh litter from plants is subject to intensive leaching, which is accompanied by the dissolution of ions from sediment particles (Fritz et al., 2015).

Right upon slumping, OM is potentially subject to rapid degradation due to mineralization by microorganisms. This is indicated by a significant decrease of $\mathrm{C} / \mathrm{N}$-ratios from 16 to 8 (TOC/TN) and 15 to 8 (DOC/DN). POC fractions within the TOC pool which are subject to less degradation, could be sorbed to mineral particles and protected by organo-mineral bonds, potentially stabilizing OM (Höfle et al., 2013; Huguet et al., 2008; Keil et al., 1994). The narrow ratios, especially for the DOC fraction in the mudpool and transition zone, reflect the high mineralization rates of OM. DOC/DN-ratios in the thaw stream are extremely low (4) indicating strong mineralization, which is typical for aerobic streams draining permafrost areas (Kokelj et al., 2013; Vonk et al., 2013). However, in contrast to C/Nratios, degradation is not reflected by $\delta^{13} \mathrm{C}$-TOC and $\delta^{13} \mathrm{C}$-DOC signatures, which did not change considerably in the disturbed zone.

Besides lower C/N-ratios and $\delta^{13} \mathrm{C}$-DOC values an increase of DIN (mainly consisting of $\mathrm{NH}_{4}-\mathrm{N}$ ) accompanied by a decrease of $\mathrm{TN}$ in the mudpool indicates active degradation of OM accompanied by the liberation of $\mathrm{NH}_{4}-\mathrm{N}$ (Ladd and Jackson, 1982). A major portion of $\mathrm{NH}_{4}-\mathrm{N}$ is however provided by thawing permafrost, where it was preserved in a frozen state (Jorgenson and Osterkamp, 2005; Mikan et al., 2002; Wilhelm et al., 2012). After thaw, this formerly preserved $\mathrm{NH}_{4}-\mathrm{N}$ is diluted with melted massive ice and accumulates in the mudpool, where it mixes with freshly mineralized $\mathrm{NH}_{4}-\mathrm{N}$ after permafrost thaw. This is supported by studies from Mackelprang et al. (2011), who showed a rapid shift and increase of ammonification genes within the first week of permafrost thaw, increasing $\mathrm{NH}_{4}$ - $\mathrm{N}$-concentrations. A fast ammonification process is typical for soils with low temperatures and tendencies towards anaerobic conditions, which are given in the water-logged mudpool (Cray and Pollard, 2015). The elevated DIN concentrations and low DOC concentrations are in good agreement with Abbott et al. (2014), who showed that the presence of labile DOC fractions, which we assume for the mudpool, are accompanied by higher DIN concentrations.

Several studies have proposed that DOC components are more labile than POC, as the DOC contributed from permafrost was possibly unprocessed before mobilization and consisted predominantly of labile low-molecular-weight and few aromatic compounds (Dutta et al., 2006; Waldrop et al., 2010). This degradation process most likely causes the formation of greenhouse gases (Schaefer et al., 2014; Schuur et al., 2015). Knoblauch et al. (2013) showed that the highest $\mathrm{OM}$ mineralization rates and $\mathrm{CO}_{2}$ production were found directly after permafrost thaw and projected a loss of initial OC of $15 \%$ within 100 years. Abbott and Jones (2015) showed that large quantities of $\mathrm{CO}_{2}$ and $\mathrm{CH}_{4}$ can be emitted from exposed mineral soils during thermokarst formation in comparison to undisturbed tundra. In addition, emission of nitrous oxide $\left(\mathrm{N}_{2} \mathrm{O}\right)$ produced by microorganisms during denitrification is reported for disturbed permafrost soils, in particular those without active vegetation (Elberling et al., 2010; Repo et al., 2009).

\subsubsection{Processes during slump stabilization}

Within the disturbed zone, overall TOC and TN remain stable after decreasing strongly following initial slumping. The TOC pool, however, increases within the slump floor, probably due to compaction of sediments, concentration of mobilized OC and additional input from modern OC sources and vegetation (e.g., Strauss et al., 2015). Lantuit et al. (2012b) showed that the shear strength of the sediment in the disturbed zone was three times that of the undisturbed one, reflecting substantial compaction of the sediment. DOC gradually decreases further towards the slump floor, with DN and DIN concentrations decreasing rapidly from the transition zone to the slump floor. A major portion of DOC and DN is probably exported with the thaw stream into the nearshore zone, while draining the slump floor. This is indicated especially by elevated DN and DIN concentrations in the thaw stream, comparable to those measured in the mudpool, and the gradual decrease in water contents towards the slump floor. This is in good agreement with the high nutrient loads (e.g., sulfur, calcium, magnesium, ammonium) that have been observed in thaw streams from different thermokarst features in upland regions of the western Canadian Arctic and Alaska (e.g., Abbott et al., 2015; Kokelj et al., 2013; Malone et al., 2013). The stabilization and 
recolonization of vegetation is most likely connected to a loss of labile DOC fractions (Abbott et al., 2014), probably turning the slump floor into a pool of recalcitrant DOC.

Our results show a loss of lipids from the mudpool to the slump floor towards the coastal cliff, indicating degradation of OM. However, low $n$-alkane concentrations do not reflect degradation from fatty acids into alkanes, indicative of degradation (Routh et al., 2014). For the peat intrusion this is different. The HPA, which gives an indication of the relative amount of fatty acids remaining in a sample (Routh et al., 2014), shows that buried peat was probably highly degraded. Low $n$-fatty acids correlate with high $n$-alkanes, indicating OM degradation in the buried peat in the slump floor, which most likely originated from the cryoturbated upper permafrost layer and is subject to humification in the disturbed zone (Andersson and Meyers, 2012). This is typical for humic TOC portions (Gustafsson et al., 2000). This pattern is similar for hop-17(21)-ene, supporting especially the degradation of buried peat, whereas OM in the mudpool and slump floor was better preserved. However, the ACLs are similar in all three samples and justify the assumption for same $\mathrm{OM}$ source for $\mathrm{CN}$ and absolute $n$-alkanes. In general, there is no visible trend of OM degradation within the disturbed zone indicated by the biomarkers, with exception of the buried peat intrusions.

After initial slumping, plants recolonize the disturbed zone - more sparsely in the transition zone, and more densely in the slump floor. Upon RTS formation, nutrients in form of nitrogen that were immobilized and preserved within the permafrost become available and can be fixated by pioneer vegetation (Cray and Pollard, 2015; Forbes and Jefferies, 1999). Early colonizers of the RTS include strongly nitrophilous grasses, which thrive on the increased bioavailability of nitrogen in newly disturbed bare ground and facilitate the DN decrease. In comparison, strong competition for nitrogen limits its bioavailability in mature vegetation in the undisturbed zone. In stabilized parts of the slump, the vegetation composition shifts towards taxa with more effective nitrogen uptake. Nitrogen-fixing legumes such as Astragalus spp. and Lupinus arcticus and ectomycorrhizal dwarf shrubs such as Salix arctica are abundant in older deposits of the slump floor. These vegetation recolonization patterns can be considered typical for RTS. Areas that stabilized roughly within the last 10 to 20 years are colonized by nitrophilous grasses (Alopecurus alpinus, Poa arctica, Puccinellia arctica, Puccinellia spp.) and forbs (Artemisia alaskana, A. arctica, A. tilesii, Matricaria ambigua, Cochlearia officinalis; Billings and Peterson, 1980; Cray and Pollard, 2015; Gill, 1973; Hernandez, 1973; Lambert, 1972). Elements of the mature vegetation, like $S$. arctica, are transported into the slump floor and re-establish there. Cray and Pollard (2015) showed that older slump floor deposits ( 250 years) are dominated by willows (Salix arctica, S. pulchra, S. reticulata) and legumes (Astragalus alpinus, Oxytropis spp.).

With stabilization of the slump floor, $\mathrm{NH}_{4}-\mathrm{N}$ concentrations decrease and $\mathrm{NO}_{3}-\mathrm{N}$ concentrations increase in individual samples. This shift is accompanied by a decrease in soil water and an increase in vegetation coverage. Within the disturbed zone, nitrite and nitrate concentrations are generally extremely low (as well as in the undisturbed zone). Noticeable nitrate concentrations are only observed as individual outliers (see Supplementary material, Table A.1). These nitrate "pockets" are detected in slump parts that have moved relatively quickly (i.e., mudflows) or in cracked surfaces, and profiles characterized by lenticular space within the clayish sediments. In these features, oxygen supply has probably supported nitrification.

OM that has not been subject to degradation or long-term accumulation in the slump floor is transported offshore into the nearshore zone by the thaw stream or erosion of the cliff (i.e., vertically exposed slump floor). Cliff erosion at the shore line currently progresses at rates of 0.6 to $0.9 \mathrm{~m}$ year $^{-1}$ (1970 to 2000) and is projected to continue (Lantuit and Pollard, 2008). Active slumps can have extremely high rates $\left(>20 \mathrm{~m} \mathrm{year}^{-1}\right)$ of erosion, but also progradate into the nearshore zone (Lantuit and Pollard, 2008; Obu et al., 2016).

\subsection{Fate of organic matter in the nearshore zone}

TOC contents are slightly higher in marine sediments from the nearshore zone than in terrestrial sediments from the disturbed zone. This is probably caused by additional input from autochtonous marine sources, which is typical for nearshore zones and estuaries (Carmack and Macdonald, 2002; Dunton et al., 2006). In general, the sediments of the nearshore zone at Qikiqtaruk are of terrestrial origin, revealed by C/ $\mathrm{N}$-ratios and $\delta^{13} \mathrm{C}$ signatures (e.g., Lamb et al., 2006 and reference therein), which was also shown for the rest of the Yukon coast (Couture, 2010). In addition, Vonk et al. (2012) showed that surface sediments in the nearshore zone of the East Siberian shelf are dominated by Yedoma deposits ( $57 \pm 1.6 \%$ ), followed by marine and planktonic OC ( $26 \pm 8.0 \%$ ), and topsoil permafrost OC (16 $\pm 3.4 \%)$, with $\delta^{13} \mathrm{C}$ signatures showing a distinct terrestrial signal between -25 and $-28 \%$, comparable to those in our study. Freshwater DOC and POC, as well as $\mathrm{C}_{3}$ land plants are probably the main sources of $\mathrm{OC}$ in close proximity to the RTS ( 50 to $400 \mathrm{~m}$ ). Field observations showed that collapsing tundra hummocks are transported along with the thaw stream and are deposited directly on the shore, where they are leached by seawater and broken down by wave action, their remains partially buried in marine sediments. Fresh water algae becomes present at 800 to $2000 \mathrm{~m}$ distance from the RTS and in the lower part ( $>6 \mathrm{~cm}$ depth) of the short core, probably due to a mix of autochtonous production within the brackish water column and the influx of allochtonous terrestrial sources from the coast, rivers, or sea ice (Matthiessen et al., 2000; Poulin et al., 2014). The influence of the Mackenzie River inflow in the eastern part of the Yukon coast is particularly strong and is probably an additional source of terrestrial OM at the study site (Carmack and Macdonald, 2002). Whereas the particulate fractions (POC) are mostly deposited before reaching Qikiqtaruk, the influx of DOC is likely to be substantial (Macdonald et al., 1998). The thaw stream provides mainly freshwater POC and microorganisms as a point source. Sediments provided by the thaw stream or erosion along the RTS cliff accumulate with sedimentation rates between 0.1 and $2.0 \mathrm{~mm} \mathrm{year}^{-1}$ (Harper and Penland, 1982). POC fractions are likely to settle quickly due to their higher weight (Gustafsson et al., 2000). Depending on the oxygen availability, terrestrially derived OM from the slump can be stabilized and preserved for longer time scales in marine sediments under anaerobic conditions (Walter et al., 2007). However, all marine sediments and OC in the water column at water depths less than $30 \mathrm{~m}$ can be affected by wave erosion, resuspension or ice-scouring, and thus long-term accumulation of OM may be limited (Are et al., 2008; Macdonald et al., 2015; Reimnitz et al., 1987; Vonk et al., 2012). Further offshore, the contribution of autochtonous sources increases gradually along the narrow shelf and towards the Alaskan Beaufort Sea and Chukchi Sea, where autochtonous production dominates (Naidu et al., 2000). However, terrestrial OM can even be transported to the shelf edge and beyond into deep water basins, where it can be stored for millennia (Belicka et al., 2002; Forest et al., 2007; Letscher et al., 2013; O'Brien et al., 2006).

\subsection{Environmental impact of the RTS}

RTS play an important role for the transformation of OM, as carbon losses are even higher than in other thermokarst features such as landslides and gullies (Abbott et al., 2015). RTS developing in fluvial and lacustrine Holocene deposits potentially release even more OM than morainal deposits, as TOC contents are much higher in these landforms (Couture, 2010). Disturbance also results in a long-term shift of terrestrial environments within the coastal fringe, as recolonization of plants can take decades and even centuries, leaving bare ground that is more susceptible to erosion (Cray and Pollard, 2015). RTS formation could also have profound impacts on biogeochemistry and food webs of aquatic systems, as they provide substantial quantities of OM and nutrients such as nitrogen or sulfur from a point source (Abbott et al., 2015; Kokelj et al., 2013; Malone et al., 2013; Moquin et al., 2014). For our 
study site, Dunton et al. (2006) showed that fish species can take up substantial amounts of carbon contributed from peat. Especially in the late season when river discharge is low and RTS activity is at its peak, this could play an important role. Moreover, as fresh water sources among rivers, sea ice and glaciers, RTS could potentially alter the stratification of the water column and thus impacting circulation patterns (Aagard and Carmack, 1989; Davis et al., 2016; Nummelin et al., 2015).

\section{Conclusion}

Terrestrial organic matter mobilized from active layer and permafrost during RTS formation is subject to substantial transformation processes in the disturbed zone before entering the ocean. TOC and DOC losses of $77 \%$ and $55 \%$ as well as TN and DN losses of $53 \%$ and $48 \%$, respectively, occur between the undisturbed and disturbed zone. In contrast to the extensive OM loss, DIN concentrations increase, mainly in the form of $\mathrm{NH}_{4}-\mathrm{N}$, which originated partially from microbial ammonification. Geochemical characteristics of OM within RTS features are strongly altered by dilution with melting massive ground ice, leaching, degradation due to microbial mineralization, immediate offshore transport and drainage via thaw streams, as well as plant uptake during vegetation recolonization. Major portions of OM are diluted and transported with the thaw stream into the nearshore zone. In the mudpool and thaw stream, OC is most likely quickly mineralized, which is probably accompanied by greenhouse gas emissions. In the slump floor, degradation occurs only in buried peat patches. Within the nearshore zone, vast portions of the OM accumulate in the vicinity of the RTS, where it can be buried on long-term timescales, resuspended and subjected to further mineralization, transported offshore and accumulated on the shelf, or even transported further into deep basins and buried for millennia. The Beaufort Sea, with its ice-cored permafrost coasts is particularly prone to the occurrence of thermokarst and could witness large OM fluxes into the nearshore zone impacting the coastal ecosystem.

Supplementary data to this article can be found online at http://dx. doi.org/10.1016/j.scitotenv.2016.12.152.

\section{Acknowledgements}

This study was funded by the Helmholtz Young Investigators Group "COPER" (grant VH-NG-801 to H. Lantuit). M. Fritz was supported by the Daimler and Benz Foundation (grant \#32-02/15). J. Strauss acknowledges the support from the European Research Council (starting grant \#338335) and the Initiative and Networking Fund of the Helmholtz Association, Germany (\#ERC-0013). We thank A. Popiel for final language correction, which was financed from the Potsdam Graduate School (POGS). We are very grateful to D. Fox, S. Stettner, and U. Kuschel for their support during the field work. We thank B. Grabellus for her support during lab work and C. Karger and K. Mangelsdorf (GFZ - German Centre for Geosciences) for biomarker measurements. We would like to especially thank R. Gordon and the rangers of the Qikiqtaruk - Herschel Island - Territorial Park for their support in the field and for sharing their local knowledge on nature and culture in the western Canadian Arctic. E. McLeod is acknowledged for his support during sampling. We further thank the Aurora Research Institute (ARI) and especially J. Gareis for their enduring support, as well as Parks Canada, the Geological Survey of Canada (GSC), and McGill University for logistical support.

\section{References}

Aagard, A., Carmack, E.C., 1989. The role of sea ice and other fresh water in the Arctic circulation. J. Geophys. Res. 94:14,485-14,498. http://dx.doi.org/10.1029/JC094iC10p14485.

Abbott, B.W., Jones, J.B., 2015. Permafrost collapse alters soil carbon stocks, respiration, $\mathrm{CH}_{4}$, and $\mathrm{N}_{2} \mathrm{O}$ in upland tundra. Glob. Chang. Biol. 21:4570-4587. http://dx.doi.org/ $10.1111 / \mathrm{gcb} .13069$.

Abbott, B.W., Larouche, J.R., Jones, J.B., Bowden, W.B., Balser, A.W., 2014. Elevated dissolved organic carbon biodegradability from thawing and collapsing permafrost. J. Geophys. Res. Biogeosci. 119:2049-2063. http://dx.doi.org/10.1002/2014JG002678.
Abbott, B.W., Jones, J.B., Godsey, S.E., Larouche, J.R., Bowden, W.B., 2015. Patterns and persistence of hydrologic carbon and nutrient export from collapsing upland permafrost. Biogeosciences 12:3725-3740. http://dx.doi.org/10.5194/bg-12-3725-2015.

Anand, R., Germon, J.-C., Groffman, P.M., Norton, J.M., Laurent, P., Prosser, J.I., Schimel, J.P., 2011. Nitrogen transformations. In: Ming Huang, P., Yuncong. L., Sumner, M.E. (Eds.), Handbook of Soil Sciences: Properties and Processes. CRC Press, Boca Raton, London, New York, Washington D.C., p. 1442.

Andersson, R.A., Meyers, P.A., 2012. Effect of climate change on delivery and degradation of lipid biomarkers in a Holocene peat sequence in the eastern European Russian Arctic. Org. Geochem. 53:63-72. http://dx.doi.org/10.1016/j.orggeochem.2012.05.002.

Are, F.E., Reimnitz, E., Grigoriev, M.N., Hubberten, H.W., Rachold, V., 2008. The influence of cryogenic processes on the erosional Arctic shoreface. J. Coast. Res. 241:110-121. http://dx.doi.org/10.2112/05-0573.1.

Artinger, R., Buckau, G., Geyer, S., Fritz, P., Wolf, M., Kim, J.I., 2000. Characterization of groundwater humic substances: influence of sedimentary organic carbon. Appl. Geochem. 15:97-116. http://dx.doi.org/10.1016/S0883-2927(99)00021-9.

Atkin, O.K., 1996. Reassessing the nitrogen relations of Arctic plants: a mini-review. Plant Cell Environ. 19:695-704. http://dx.doi.org/10.1111/j.1365-3040.1996.tb00404.x.

Atkinson, D.E., 2005. Observed storminess patterns and trends in the circum-Arctic coastal regime. Geo-Mar. Lett. 25:98-109. http://dx.doi.org/10.1007/s00367-004-0191-0.

Belicka, L., Macdonald, R., Harvey, H., 2002. Sources and transport of organic carbon to shelf, slope, and basin surface sediments of the Arctic Ocean. Deep-Sea Res. I Oceanogr. Res. Pap. 49:1463-1483. http://dx.doi.org/10.1016/S0967-0637(02)00031-6.

Billings, W.D., Peterson, K.M., 1980. Vegetational change and ice-wedge polygons through the thaw-lake cycle in Arctic Alaska. Arct. Alp. Res. 12:413-432. http://dx.doi.org/10. 2307/1550492.

Blasco, S.M., Fortin, G., Hill, P.R., O'Connor, M.J., Brigham-Grette, J.K., 1990. The late Neogene and Quaternary stratigraphy of the Canadian Beaufort continental shelf. In: Grantz, A., Johnson, L., Sweeney, J.F. (Eds.), The Arctic Ocean Region. Geological Society of America, The Geology of North America, pp. 491-502.

Bowden, W.B., Gooseff, M.N., Balser, A., Green, A., Peterson, B.J., Bradford, J., 2008. Sediment and nutrient delivery from thermokarst features in the foothills of the North Slope, Alaska: potential impacts on headwater stream ecosystems. J. Geophys. Res. Biogeosci. 113:1-12. http://dx.doi.org/10.1029/2007JG000470.

Bray, E.E., Evans, E.D., 1961. Distribution of $n$-paraffins as a clue to recognition of source beds. Geochim. Cosmochim. Acta 22:2-15. http://dx.doi.org/10.1016/00167037(61)90069-2.

Burn, C.R., 2012. Herschel Island Qikiqtaryuk - a Natural and Cultural History of Yukon's Arctic Island. Calgary, Alberta.

Burn, C.R., Zhang, Y., 2009. Permafrost and climate change at Herschel Island (Qikiqtaruq), Yukon territory, Canada. J. Geophys. Res. Earth Surf. 114:1-16. http://dx.doi.org/10. 1029/2008JF001087.

Carmack, E.C., Macdonald, R.W., 2002. Oceanography of the Canadian shelf of the Beaufort Sea: a setting for marine life. Arctic 55:29-45. http://dx.doi.org/10.1126/science.100. 2596.291.

Cassidy, A.E., Christen, A., Henry, G.H.R., 2016. The effect of a permafrost disturbance on growing-season carbon-dioxide fluxes in a high Arctic tundra ecosystem. Biogeosciences 13:2291-2303. http://dx.doi.org/10.5194/bg-13-2291-2016.

Collins, M., Knutti, R., Arblaster, J., Dufresne, J.-L., Fichefet, T., Friedlingstein, P., Gao, X., Gutowski, W.J., Johns, T., Krinner, G., Shongwe, M., Tebaldi, C., Wehner, A.J., Weaver, M., 2013. Long-term climate change: projections, commitments and irreversibility. In: Stocker, T.F., Qin, D., Plattner, G.-K., Tignor, M., Allen, S.K., Boschung, J., Nauels, A., Xia, Y., Bex, V., Midgley, P.M. (Eds.), Climate Change 2013: The Physical Science Basis. Contribution of Working Group I to the Fifth Assessment Report of the Intergovernmental Panel on Climate Change. Cambridge University Press, Cambridge, United Kingdom and New York, NY, USA.

Cory, R.M., Crump, B.C., Dobkowski, J.A., Kling, G.W., 2013. Surface exposure to sunlight stimulates $\mathrm{CO}_{2}$ release from permafrost soil carbon in the Arctic. Proc. Natl. Acad. Sci. U. S. A. 110:3429-3434. http://dx.doi.org/10.1073/pnas.1214104110.

Couture, N., 2010. Fluxes of Soil Organic Carbon From Eroding Permafrost Coasts, Canadian Beaufort Sea. (PhD thesis). McGill University, Montréal, Canada.

Couture, N., Pollard, W.H., 2015. Ground ice determinations along the Yukon coast using a morphological model. Proceedings, GeoQuebec 2015, 7th Canadian Permafrost Conference. Québec City, Canada.

Cray, H., Pollard, W.H., 2015. Vegetation recovery patterns following permafrost disturbance in a low Arctic vegetation recovery patterns following permafrost disturbance in a low Arctic setting: case study of Herschel Island, Yukon, Canada. Arct. Antarct. Alp. Res. 47:99-113. http://dx.doi.org/10.1657/AAAR0013-076.

Czudek, T., Demek, J., 1970. Thermokarst in Siberia and its influence on the development of lowland relief. Quat. Res. 1:103-120. http://dx.doi.org/10.1016/00335894(70)90013-X

Davis, P.E.D., Lique, C., Johnson, H.L., Guthrie, J.D., 2016. Competing effects of elevated vertical mixing and increased freshwater input on the stratification and sea ice cover in a changing Arctic Ocean. J. Phys. Oceanogr. 160203133647008. http://dx.doi.org/10. 1175/JPO-D-15-0174.1.

de Krom, V., 1990. Retrogressive Thaw Slumps and Active Layer Slides on Herschel Island, Yukon. (MSc. thesis). McGill University, Montréal, Canada.

Dou, F., Ping, C.-L., Guo, L., Jorgenson, T., 2008. Estimating the impact of seawater on the production of soil water-extractable organic carbon during coastal erosion. J. Environ. Qual. 37:2368-2374. http://dx.doi.org/10.2134/jeq2007.0403.

Dunton, K.H., Weingartner, T., Carmack, E.C., 2006. The nearshore western Beaufort Sea ecosystem: circulation and importance of terrestrial carbon in arctic coastal food webs. Prog. Oceanogr. 71:362-378. http://dx.doi.org/10.1016/j.pocean.2006.09.011.

Dutta, K., Schuur, E.A.G., Neff, J.C., Zimov, S.A., 2006. Potential carbon release from permafrost soils of northeastern Siberia. Glob. Chang. Biol. 12:2336-2351. http://dx.doi.org/ 10.1111/j.1365-2486.2006.01259.x. 
Elberling, B., Christiansen, H.H., Hansen, B.U., 2010. High nitrous oxide production from thawing permafrost. Nat. Geosci. 3:506. http://dx.doi.org/10.1038/ngeo893.

Forbes, B.C., Jefferies, R.L., 1999. Revegetation of disturbed arctic sites: constraints and applications. Biol. Conserv. 88:15-24. http://dx.doi.org/10.1016/S0006-3207(98)00095-0.

Forbes, D.L., Kremer, H., Lantuit, H., Rachold, V., Reiersen, O., 2011. State of the Arctic Coast 2010: Scientific Review and Outlook. International Arctic Science Committee, LandOcean Interactions in the Coastal Zone, Arctic Monitoring and Assessment Programme, International Permafrost Association, Geesthacht, Germany.

Forest, A., Sampei, M., Hattori, H., Makabe, R., Sasaki, H., Fukuchi, M., Wassmann, P., Fortier, L., 2007. Particulate organic carbon fluxes on the slope of the Mackenzie shelf (Beaufort Sea): physical and biological forcing of shelf-basin exchanges. J. Mar. Syst. 68:39-54. http://dx.doi.org/10.1016/j.jmarsys.2006.10.008.

French, H., Shur, Y., 2010. The principles of cryostratigraphy. Earth Sci. Rev. 101:190-206. http://dx.doi.org/10.1016/j.earscirev.2010.04.002.

Frey, K.E., McClelland, J.W., Holmes, R.M., Smith, L.G., 2007. Impacts of climate warming and permafrost thaw on the riverine transport of nitrogen and phosphorus to the Kara Sea. J. Geophys. Res. Biogeosci. 112:1-10. http://dx.doi.org/10.1029/2006JG000369.

Fritz, M., Wetterich, S., Meyer, H., Schirrmeister, L., Lantuit, H., Pollard, W.H., 2011. Origin and characteristics of massive ground ice on Herschel Island (western Canadian Arctic) as revealed by stable water isotope and hydrochemical signatures. Permafr. Periglac. Process. 22:26-38. http://dx.doi.org/10.1002/ppp.714.

Fritz, M., Wetterich, S., Schirrmeister, L., Meyer, H., Lantuit, H., Preusser, F., Pollard, W.H., 2012. Eastern Beringia and beyond: Late Wisconsinan and Holocene landscape dynamics along the Yukon Coastal Plain, Canada. Palaeogeogr. Palaeoclimatol. Palaeoecol. 319-320:28-45. http://dx.doi.org/10.1016/j.palaeo.2011.12.015.

Fritz, M., Opel, T., Tanski, G., Herzschuh, U., Meyer, H., Eulenburg, A., Lantuit, H., 2015. Dissolved organic carbon (DOC) in Arctic ground ice. Cryosphere 9:737-752. http://dx. doi.org/10.5194/tc-9-737-2015.

Gill, D., 1973. Floristics of a plant succession sequence in the Mackenzie Delta, Northwest Territories. Polarforschung 51, 55-65.

Grosse, G., Romanovsky, V., Jorgenson, T., Walter Anthony, K.M., Brown, J., Overduin, P.P., 2011. Vulnerability and feedbacks of permafrost to climate change. EOS Trans. Am. Geophys. Union 92:73-80. http://dx.doi.org/10.1029/2011EO090001.

Gundelwein, A., Müller-Lupp, T., Sommerkorn, M., Haupt, E.T.K., Pfeiffer, E.M., Wiechmann, H., 2007. Carbon in tundra soils in the Lake Labaz region of arctic Siberia. Eur. J. Soil Sci. 58:1164-1174. http://dx.doi.org/10.1111/j.1365-2389.2007.00908.x.

Guo, L., Ping, C.L., Macdonald, R.W., 2007. Mobilization pathways of organic carbon from permafrost to arctic rivers in a changing climate. Geophys. Res. Lett. 34:1-5. http://dx. doi.org/10.1029/2007GL030689.

Gustafsson, Ö., Widerlund, A., Andersson, P.S., Ingri, J., Roos, P., Ledin, A., 2000. Colloid dynamics and transport of major elements through a boreal river - brackish bay mixing zone. Mar. Chem. 71:1-21. http://dx.doi.org/10.1016/S0304-4203(00)00035-9.

Harden, J.W., Koven, C.D., Ping, C.L., Hugelius, G., McGuire, D.A., Camill, P., Jorgenson, T., Kuhry, P., Michaelson, G.J., O'Donnell, J.A., Schuur, E.A.G., Tarnocai, C., Johnson, K., Grosse, G., 2012. Field information links permafrost carbon to physical vulnerabilities of thawing. Geophys. Res. Lett. 39:1-6. http://dx.doi.org/10.1029/2012GL051958.

Harper, J.R., Penland, P.S., 1982. Beaufort Sea sediment dynamics. Technical Report for Geological Survey of Canada. Victoria, British Columbia.

Hernandez, H., 1973. Natural plant recolonization of surficial disturbances, Tuktoyaktuk Peninsula Region, Northwest Territories. Can. J. Bot. 51:2177-2196. http://dx.doi. org/10.1139/b73-280.

Höfle, S., Rethemeyer, J., Mueller, C.W., John, S., 2013. Organic matter composition and stabilization in a polygonal tundra soil of the Lena Delta. Biogeosciences 10: 3145-3158. http://dx.doi.org/10.5194/bg-10-3145-2013.

Hugelius, G., Strauss, J., Zubrzycki, S., Harden, J.W., Schuur, E.A.G., Ping, C.L., Schirrmeister, L., Grosse, G., Michaelson, G.J., Koven, C.D., O'Donnell, J.A., Elberling, B., Mishra, U. Camill, P., Yu, Z., Palmtag, J., Kuhry, P., 2014. Estimated stocks of circumpolar permafrost carbon with quantified uncertainty ranges and identified data gaps. Biogeosciences 11:6573-6593. http://dx.doi.org/10.5194/bg-11-6573-2014.

Huguet, C., de Lange, G.J., Gustafsson, Ö., Middelburg, J.J., Sinninghe Damsté, J.S., Schouten, S., 2008. Selective preservation of soil organic matter in oxidized marine sediments (Madeira Abyssal Plain). Geochim. Cosmochim. Acta 72:6061-6068. http://dx.doi. org/10.1016/j.gca.2008.09.021.

Jorgenson, M.T., Osterkamp, T.E., 2005. Response of boreal ecosystems to varying modes of permafrost degradation. Can. J. For. Res. 35:2100-2111. http://dx.doi.org/10. 1139/x05-153.

Kawahigashi, M., Kaiser, K., Kalbitz, K., Rodionov, A., Guggenberger, G., 2004. Dissolved organic matter in small streams along a gradient from discontinuous to continuous permafrost. Glob. Chang. Biol. 10:1576-1586. http://dx.doi.org/10.1111/j.1365-2486. 2004.08827.x.

Keil, R.G., Montluçon, D.B., Prahl, F.G., Hedges, J.I., 1994. Sorptive preservation of labile organic matter in marine sediments. Nature 370:549-552. http://dx.doi.org/10.1038/ $370549 \mathrm{a} 0$

Kennedy, C.E., Smith, C.A.S., Cooley, D.A., 2001. Observations of change in the cover of polargrass, Arctagrostis latifolia, and arctic lupine, Lupinus arcticus, in upland tundra on Herschel Island, Yukon territory. Can. F. Nat. 115, 323-328.

Knoblauch, C., Beer, C., Sosnin, A., Wagner, D., Pfeiffer, E.M., 2013. Predicting long-term carbon mineralization and trace gas production from thawing permafrost of northeast Siberia. Glob. Chang. Biol. 19:1160-1172. http://dx.doi.org/10.1111/gcb.12116.

Kokelj, S.V., Jorgenson, M.T., 2013. Advances in thermokarst research. Permafr. Periglac. Process. 24:108-119. http://dx.doi.org/10.1002/ppp.1779.

Kokelj, S.V., Smith, C.A.S., Burn, C.R., 2002. Physical and chemical characteristics of the active layer and permafrost, Herschel Island, western Arctic coast, Canada. Permafr. Periglac. Process. 13:171-185. http://dx.doi.org/10.1002/ppp.417.

Kokelj, S.V., Lacelle, D., Lantz, T.C., Tunnicliffe, J., Malone, L., Clark, I.D., Chin, K.S., 2013. Thawing of massive ground ice in mega slumps drives increases in stream sediment and solute flux across a range of watershed scales. J. Geophys. Res. Earth Surf. 118: 681-692. http://dx.doi.org/10.1002/jgrf.20063.

Krieger, K.E., 2012. The Topographic Form and Evolution of Thermal Erosion Features: A First Analysis Using Airborne and Ground-based LiDAR in Arctic Alaska. (MSc. thesis). Idaho State University, USA.

Krom, M.D., Berner, R.A., 1980. The diffusion-coefficients of sulfate, ammonium, and phosphate ions in anoxic marine-sediments. Limnol. Oceanogr. 25, 327-337.

Kuhry, P., Vitt, D.H., 1996. Fossil carbon/nitrogen ratios as a measure of peat decomposition. Ecol. Soc. Am. 77:271-275. http://dx.doi.org/10.2307/2265676.

Ladd, J.N., Jackson, R.B., 1982. Biochemistry of ammonification. In: Stevenson, F.J. (Ed.), Nitrogen in Agricultural Soils. American Society of Agronomy, Monogrpahy no. 22, Madison, USA, pp. 173-228.

Lamb, A.L., Wilson, G.P., Leng, M.J., 2006. A review of coastal palaeoclimate and relative sea-level reconstructions using $\delta^{13} \mathrm{C}$ and $\mathrm{C} / \mathrm{N}$ ratios in organic material. Earth Sci. Rev. 75:29-57. http://dx.doi.org/10.1016/j.earscirev.2005.10.003.

Lambert, J., 1972. Plant succession on tundra mudflows: preliminary observations. Arctic http://dx.doi.org/10.1016/0022-4898(73)90216-4.

Lantuit, H., Pollard, W.H., 2005. Temporal stereophotogrammetric analysis of retrogressive thaw slumps on Herschel Island, Yukon territory. Nat. Hazards Earth Syst. Sci. 5:413-423. http://dx.doi.org/10.5194/nhess-5-413-2005.

Lantuit, H., Pollard, W.H., 2008. Fifty years of coastal erosion and retrogressive thaw slump activity on Herschel Island, southern Beaufort Sea, Yukon territory, Canada. Geomorphology 95:84-102. http://dx.doi.org/10.1016/j.geomorph.2006.07. 040.

Lantuit, H., Overduin, P.P., Couture, N., Wetterich, S., Aré, F., Atkinson, D., Brown, J., Cherkashov, G., Drozdov, D., Donald Forbes, L., Graves-Gaylord, A., Grigoriev, M., Hubberten, H.W., Jordan, J., Jorgenson, T., Ødegård, R.S., Ogorodov, S., Pollard, W.H. Rachold, V., Sedenko, S., Solomon, S., Steenhuisen, F., Streletskaya, I., Vasiliev, A. 2012a. The Arctic coastal dynamics database: a new classification scheme and statistics on Arctic permafrost coastlines. Estuar. Coasts 35:383-400. http://dx.doi.org/10. 1007/s12237-010-9362-6.

Lantuit, H., Pollard, W.H., Couture, N., Fritz, M., Schirrmeister, L., Meyer, H., Hubberten, H.W., 2012b. Modern and Late Holocene retrogressive thaw slump activity on the Yukon Coastal Plain and Herschel Island, Yukon territory, Canada. Permafr. Periglac. Process. 23:39-51. http://dx.doi.org/10.1002/ppp.1731.

Lantz, T.C., Kokelj, S.V., 2008. Increasing rates of retrogressive thaw slump activity in the Mackenzie Delta region, N.W.T., Canada. Geophys. Res. Lett. 35:1-5. http://dx.doi.org/ 10.1029/2007GL032433.

Letscher, R.T., Hansell, D.A., Kadko, D., 2011. Rapid removal of terrigenous dissolved organic carbon over the Eurasian shelves of the Arctic Ocean. Mar. Chem. 123:78-87. http://dx.doi.org/10.1016/j.marchem.2010.10.002.

Letscher, R.T., Hansell, D.A., Kadko, D., Bates, N.R., 2013. Dissolved organic nitrogen dynamics in the Arctic Ocean. Mar. Chem. 148:1-9. http://dx.doi.org/10.1016/j. marchem.2012.10.002.

Lide, D.R., Haynes, W.M., Baysinger, G., Kehiaian, H.V., Berger, L.I., Kuchitsu, K., Frenkel, M. Goldberg, R.N., Roth, D.L., Zwillinger, D., 2009. Properties of ice and supercooled water. In: Lide, D.R., Haynes, W.M. (Eds.), RC Handbook of Chemistry and Physics. CRC Press LLC, Taylor \& Francis Group, Boca Raton, London, New York, pp. 6-12.

Luo, Q., Yu, S., Liu, Y., Zhang, Y., Han, H., Qi, L., Zhong, N., 2012. Existence and implications of hop-17(21)-enes in the lower Cretaceous of the Saihantala Sag, Erlian basin, China. Pet. Sci. 9:154-160. http://dx.doi.org/10.1007/s12182-012-0195-8.

Macdonald, R.W., Solomon, S.M., Cranston, R.E., Welch, H.E., Yunker, M.B., Gobeil, C., 1998. A sediment and organic carbon budget for the Canadian Beaufort shelf. Mar. Geol. 144:255-273. http://dx.doi.org/10.1016/S0025-3227(97)00106-0.

Macdonald, R.W., Kuzyk, Z.Z.A., Johanessen, S.C., 2015. The vulnerability of Arctic shelf sediments to climate change. Environ. Rev. 23:461-479. http://dx.doi.org/10.1139/ er-2015-0040.

Mackelprang, R., Waldrop, M.P., DeAngelis, K.M., David, M.M., Chavarria, K.L., Blazewicz, S.J., Rubin, E.M., Jansson, J.K., 2011. Metagenomic analysis of a permafrost microbia community reveals a rapid response to thaw. Nature 480:368-371. http://dx.doi. org/10.1038/nature10576.

Malone, L., Lacelle, D., Kokelj, S., Clark, I.D., 2013. Impacts of hillslope thaw slumps on the geochemistry of permafrost catchments (Stony Creek watershed, NWT, Canada). Chem. Geol. 356:38-49. http://dx.doi.org/10.1016/j.chemgeo.2013.07.010.

Marzi, R., Torkelson, B.E., Olson, R.K., 1993. A revised carbon preference index. Org. Geochem. 20:1303-1306. http://dx.doi.org/10.1016/0146-6380(93)90016-5.

Matthiessen, J., Kunz-Pirrung, M., Mudie, P.J., 2000. Freshwater chlorophycean algae in recent marine sediments of the Beaufort, Laptev and Kara seas (Arctic Ocean) as indicators of river runoff. Int. J. Earth Sci. 89:470-485. http://dx.doi.org/10.1007/ s005310000127.

Mikan, C.J., Schimel, J.P. Doyle, A.P. 2002. Temperature controls of microbial respiration in arctic tundra soils above and below freezing. Soil Biol. Biochem. 34:1785-1795. http://dx.doi.org/10.1016/S0038-0717(02)00168-2.

Moquin, P.A., Mesquita, P.S., Wrona, F.J., Prowse, T.D., 2014. Responses of benthic invertebrate communities to shoreline retrogressive thaw slumps in Arctic upland lakes. Freshw. Sci. 33:1108-1118. http://dx.doi.org/10.1086/678700.

Myers-Smith, I.H., Hik, D.S., Kennedy, C., Cooley, D., Johnstone, J.F., Kenney, A.J., Krebs, C.J., 2011. Expansion of canopy-forming willows over the twentieth century on Herschel Island, Yukon territory, Canada. Ambio 40:610-623. http://dx.doi.org/10.1007/ s13280-011-0168-y.

Naidu, A.S., Cooper, L.W., Finney, B.P., Macdonald, R.W., Alexander, C., Semiletov, I.P., 2000. Organic carbon isotope ratio $\left(\delta^{13} \mathrm{C}\right)$ of Arctic Amerasian continental shelf sediments. Int. J. Earth Sci. http://dx.doi.org/10.1007/s005310000121.

Nummelin, A., Ilicak, M., Li, C., Smedsrud, L.H., 2015. Consequences of future increased Arctic runoff on Arctic Ocean stratification, circulation, and sea ice cover. J. Geophys. Res. Oceans 121:617-637. http://dx.doi.org/10.1002/2015JC011156. 
O'Brien, M.C., Macdonald, R.W., Melling, H., Iseki, K., 2006. Particle fluxes and geochemistry on the Canadian Beaufort shelf: implications for sediment transport and deposition. Cont. Shelf Res. 26:41-81. http://dx.doi.org/10.1016/j.csr.2005.09.007.

Obu, J., Lantuit, H., Grosse, G., Günther, F., Sachs, T., Helm, V., Fritz, M., 2016. Coastal erosion and mass wasting along the Canadian Beaufort Sea based on annual airborne LiDAR elevation data. Geomorphology. http://dx.doi.org/10.1016/j.geomorph.2016. 02.014.

Pelletier, B.R., Medioli, B.E., 2014. Environmental atlas of the Beaufort coastlands. Geol. Surv. Can. Open File 7619:1-271. http://dx.doi.org/10.4095/294601.

Pizano, C., Barón, A.F., Schuur, E.A.G., Crummer, K.G., Mack, M.C., 2014. Effects of thermoerosional disturbance on surface soil carbon and nitrogen dynamics in upland arctic tundra. Environ. Res. Lett. 9:75006. http://dx.doi.org/10.1088/1748-9326/9/7/075006.

Poulin, M., Underwood, G.J.C., Michel, C., 2014. Sub-ice colonial Melosira arctica in Arctic first-year ice. Diatom Res. 29:213-221. http://dx.doi.org/10.1080/0269249X.2013. 877085.

Poynter, J., 1989. Molecular Stratigraphy: The Recognition of Palaeo-climatic Signals in Organic Geochemical Data. (PhD thesis). University of Bristol, UK.

Prosser, J.I., 1990. Autotrophic nitrification in bacteria. Adv. Microb. Physiol. 30:125-181. http://dx.doi.org/10.1016/S0065-2911(08)60112-5.

Rampton, V.N., 1982. Quaternary geology of the Yukon Coastal Plain. Geol. Surv. Can. Bull. 317, 49.

Reimnitz, E., Kempema, E.W., Barnes, P.W., 1987. Anchor ice, seabed freezing, and sediment dynamics in shallow Arctic seas. J. Geophys. Res. 92:14,671-14,678. http://dx. doi.org/10.1029/JC092iC13p14671.

Repo, M.E., Susiluoto, S., Lind, S.E., Jokinen, S., Elsakov, V., Biasi, C., Virtanen, T. Martikainen, P.J., 2009. Large $\mathrm{N}_{2} \mathrm{O}$ emissions from cryoturbated peat soil in tundra. Nat. Geosci. 2:189-192. http://dx.doi.org/10.1038/NGEO434.

Routh, J., Hugelius, G., Kuhry, P., Filley, T., Tillman, P.K., Becher, M., Crill, P., 2014. Multiproxy study of soil organic matter dynamics in permafrost peat deposits reveal vulnerability to climate change in the European Russian Arctic. Chem. Geol. 368: 104-117. http://dx.doi.org/10.1016/j.chemgeo.2013.12.022.

Schaefer, K., Lantuit, H., Romanovsky, V.E., Schuur, E.A.G., Witt, R., 2014. The impact of the permafrost carbon feedback on global climate. Environ. Res. Lett. 9:85003. http://dx doi.org/10.1088/1748-9326/9/8/085003.

Schuur, E.A.G., Bockheim, J., Canadell, J.P., Euskirchen, E., Field, C.B., Goryachkin, S.V. Kuhry, P., Lafleur, P.M., Lee, H., Mazhitova, G., Nelson, F.E., Rinke, A., Romanovsky, V.E., Shiklomanov, N., Tarnokai, C., Venevsky, S., Vogel, J.G., Zimov, S.A., 2008. Vulnerability of permafrost carbon to climate change: implications for the global carbon cycle. Bioscience 58:701-714. http://dx.doi.org/10.1641/B580807.

Schuur, E.A.G., McGuire, A.D., Grosse, G., Harden, J.W., Hayes, D.J., Hugelius, G., Koven, C.D Kuhry, P., 2015. Climate change and the permafrost carbon feedback. Nature 520: 171-179. http://dx.doi.org/10.1038/nature14338.

Segal, R.A., Lantz, T.C., Kokelj, S.V., 2016. Acceleration of thaw slump activity in glaciated landscapes of the western Canadian Arctic. Environ. Res. Lett. 11:34025. http://dx doi.org/10.1088/1748-9326/11/3/034025.

Smith, C.A.S., Kennedy, C.E., Hargrave, A.E., McKenna, K.M., 1989. Soil and vegetation of Herschel Island, Yukon territory. Yukon Soil Survey Report No. 1. Whitehorse, Canada.

Solomon, S.M., 2005. Spatial and temporal variability of shoreline change in the BeaufortMackenzie region, northwest territories, Canada. Geo-Mar. Lett. 25:127-137. http:// dx.doi.org/10.1007/s00367-004-0194-x.

Stedmon, C.A., Markager, S., 2005. Resolving the variability of dissolved organic matte fluorescence in a temperate estuary and its catchment using PARAFAC analysis. Limnol. Oceanogr. 50:686-697. http://dx.doi.org/10.4319/lo.2005.50.2.0686.
Stevenson, F.J., 1994. Humus Chemistry: Genesis, Composition, Reactions. John Wiley \& Sons, New York.

St-Jean, G., 2003. Automated quantitative and isotopic $\left({ }^{13} \mathrm{C}\right)$ analysis of dissolved inorganic carbon and dissolved organic carbon in continuous-flow using a total organic carbon analyser. Rapid Commun. Mass Spectrom. 17:419-428. http://dx.doi.org/10. $1002 / \mathrm{rcm} .926$.

Strauss, J., Schirrmeister, L., Wetterich, S., Borchers, A., Davydov, S.P., 2012. Grain-size properties and organic-carbon stock of Yedoma ice complex permafrost from the Kolyma lowland, northeastern Siberia. Glob. Biogeochem. Cycles 26:1-12. http://dx.doi. org/10.1029/2011GB004104.

Strauss, J., Schirrmeister, L., Mangelsdorf, K., Eichhorn, L., Wetterich, S., Herzschuh, U., 2015. Organic-matter quality of deep permafrost carbon - a study from Arctic Siberia. Biogeosciences 12:2227-2245. http://dx.doi.org/10.5194/bg-12-2227-2015.

Tanski, G., Couture, N., Lantuit, H., Eulenburg, A., Fritz, M., 2016. Eroding permafrost coasts release low amounts of dissolved organic carbon (DOC) from ground ice into the nearshore zone of the Arctic Ocean. Glob. Biogeochem. Cycles 30:1054-1068. http://dx.doi.org/10.1002/2015GB005337.

Turetsky, M.R., Wieder, R.K., Vitt, D.H., Evans, R.J., Scott, K.D., 2007. The disappearance of relict permafrost in boreal north America: effects on peatland carbon storage and fluxes. Glob. Chang. Biol. 13:1922-1934. http://dx.doi.org/10.1111/j.1365-2486. 2007.01381.x.

Vonk, J.E., Sánchez-García, L., van Dongen, B.E., Alling, V., Kosmach, D., Charkin, A Semiletov, I.P., Dudarev, O.V., Shakhova, N., Roos, P., Eglinton, T.I., Andersson, A., Gustafsson, Ö., 2012. Activation of old carbon by erosion of coastal and subsea permafrost in Arctic Siberia. Nature 489:137-140. http://dx.doi.org/10.1038/nature11392.

Vonk, J.E., Mann, P.J., Davydov, S., Davydova, A., Spencer, R.G.M., Schade, J., Sobczak, W.V., Zimov, N., Zimov, S., Bulygina, E., Eglinton, T.I., Holmes, R.M., 2013. High biolability of ancient permafrost carbon upon thaw. Geophys. Res. Lett. 40:2689-2693. http://dx. doi.org/10.1002/grl.50348.

Vonk, J.E., Semiletov, I.P., Dudarev, O.V., Eglinton, T.I., Andersson, A., Shakhova, N., Charkin, A., Heim, B., Gustafsson, Ö., 2014. Preferential burial of permafrost-derived organic carbon in Siberian-Arctic shelf waters. J. Geophys. Res. Oceans 119:8410-8421. http://dx.doi.org/10.1002/2014JC010261.

Waldrop, M.P., Wickland, K.P., White, R., Berhe, A.A., Harden, J.W., Romanovsky, V.E., 2010. Molecular investigations into a globally important carbon pool: permafrostprotected carbon in Alaskan soils. Glob. Chang. Biol. 16:2543-2554. http://dx.doi. org/10.1111/j.1365-2486.2009.02141.x.

Walter, K.M., Edwards, M.E., Grosse, G., Zimov, S.A., Chapin, F.S., 2007. Thermokarst lakes as a source of atmospheric $\mathrm{CH}_{4}$ during the last deglaciation. Science 318 (80): 633-636. http://dx.doi.org/10.1126/science.1142924.

Weiss, N., Blok, D., Elberling, B., Hugelius, G., Jørgensen, C.J., Siewert, M.B., Kuhry, P., 2015. Thermokarst dynamics and soil organic matter characteristics controlling initial carbon release from permafrost soils in the Siberian Yedoma region. Sediment. Geol. 340:38-48. http://dx.doi.org/10.1016/j.sedgeo.2015.12.004.

Wilhelm, R.C., Radtke, K.J., Mykytczuk, N.C.S., Greer, C.W., Whyte, L.G., 2012. Life at the wedge: the activity and diversity of Arctic ice wedge microbial communities. Astrobiology 12:347-360. http://dx.doi.org/10.1089/ast.2011.0730.

Woods, G.C., Simpson, M.J., Pautler, B.G., Lamoureux, S.F., Lafrenière, M.J., Simpson, A.J., 2011. Evidence for the enhanced lability of dissolved organic matter following permafrost slope disturbance in the Canadian High Arctic. Geochim. Cosmochim. Acta 75:7226-7241. http://dx.doi.org/10.1016/j.gca.2011.08.013.

Zimov, S.A., Davydov, S.P., Zimova, G.M., Davydova, A.I., Schuur, E.A.G., Dutta, K., Chapin, I.S., 2006. Permafrost carbon: stock and decomposability of a globally significant carbon pool. Geophys. Res. Lett. 33:1-5. http://dx.doi.org/10.1029/2006GL027484. 